\title{
Structural Controls of Uranium Mineralization in the Basement of the Athabasca Basin, Saskatchewan, Canada
}

\author{
Antonio Benedicto ${ }^{D},{ }^{1}$ Maher Abdelrazek, ${ }^{1}$ Patrick Ledru, ${ }^{2}$ Cameron MacKay, ${ }^{3}$ \\ and Dwayne Kinar ${ }^{4}$ \\ ${ }^{1}$ UMR CNRS 8148 GEOPS, Université Paris-Saclay, 91405 Orsay, France \\ ${ }^{2}$ Université de Lorraine, 54506 Vandoeuvre-les-Nancy, France \\ ${ }^{3}$ Purepoint Uranium Group Inc., 530-111 2nd Ave S, Saskatoon, S7K 1K6, Canada \\ ${ }^{4}$ Orano Canada, 100-833 45th Street West, Saskatoon, Saskatchewan, S7L 5X2, Canada
}

Correspondence should be addressed to Antonio Benedicto; antonio.benedicto@u-psud.fr

Received 30 October 2019; Revised 16 December 2020; Accepted 5 January 2021; Published 24 February 2021

Academic Editor: Christophe Renac

Copyright (c) 2021 Antonio Benedicto et al. This is an open access article distributed under the Creative Commons Attribution License, which permits unrestricted use, distribution, and reproduction in any medium, provided the original work is properly cited.

\begin{abstract}
The occurrence of unconformity-related uranium mineralization requires the combination of three components: fluids with the right composition, geochemical traps with the right agents that produce precipitation, and structural traps with the right geometry. In the Athabasca Basin unconformity-related uranium deposits, while basinal brines are commonly accepted as the principal mineralized fluids and graphite and gases $\left(\mathrm{CH}_{4}, \mathrm{CO}_{2}\right.$, and $\left.\mathrm{H}_{2} \mathrm{~S}\right)$ are well known as the reductants, only few case studies describing structural traps are published. A number of recent works, including numerical modelling, have improved the understanding of the role of inherited shear zones on fluid flow and the development of uranium deposits at a micro- and regional-scale. Nevertheless, there is still a lack of knowledge about the meso- or deposit-scale structural controls that lead to the present (and potentially predictive) localization of uranium deposits along a given shear zone. The present work examines new structural data from drill holes and deals with (i) the identification of mesoscale structural traps that lead to the formation of the Athabasca unconformity-related uranium deposits hosted within the basement and (ii) with the understanding of the role and mode of reactivation of the inherited shear zones. The Sue deposits (McClean Project), the Tri-Island showing (Martin Lake Project) in the Eastern Athabasca, and the Spitfire prospect (Hook Lake Project) in the Western Athabasca have been selected for a detailed analysis of structures and related uranium mineralization. The structural analysis performed brings new insights about the mesoscale structural controls, the role the inherited ductile fabric had on the mode of brittle reactivation and to trap mineralization, and the tectonic regime to which basement-hosted uranium deposits may be associated in the Athabasca Basin.
\end{abstract}

\section{Introduction}

Unconformity-related uranium mineralization is the result of a combination of multiple processes and episodes of fluidrock interaction with mineral reactions that operate during fault formation and reactivation, leading to multifaceted mineralization settings. The right combination of three components is required for this to work: fluids with the right composition, structural traps with the right geometry, and geochemical traps with the right agents that produce precipitation. Thus, metallic mineralization is often hosted in long- lived crustal-scale fault-systems where these three components often combine, the migration and trapping of fluids being controlled by the geometry and polyphased activity of the plumbing system (i.e., $[1,2]$ ) and the nature of the physical and geochemical barriers that trigger precipitation of ore (i.e., [3, 4]). This is the case of the basement-hosted unconformity-related uranium deposits of the Canadian Paleo to Mesoproterozoic Athabasca (Figure 1) and Thelon basins [5-8].

Structural controls of unconformity-related uranium deposits in the Athabasca and Thelon basins have been 


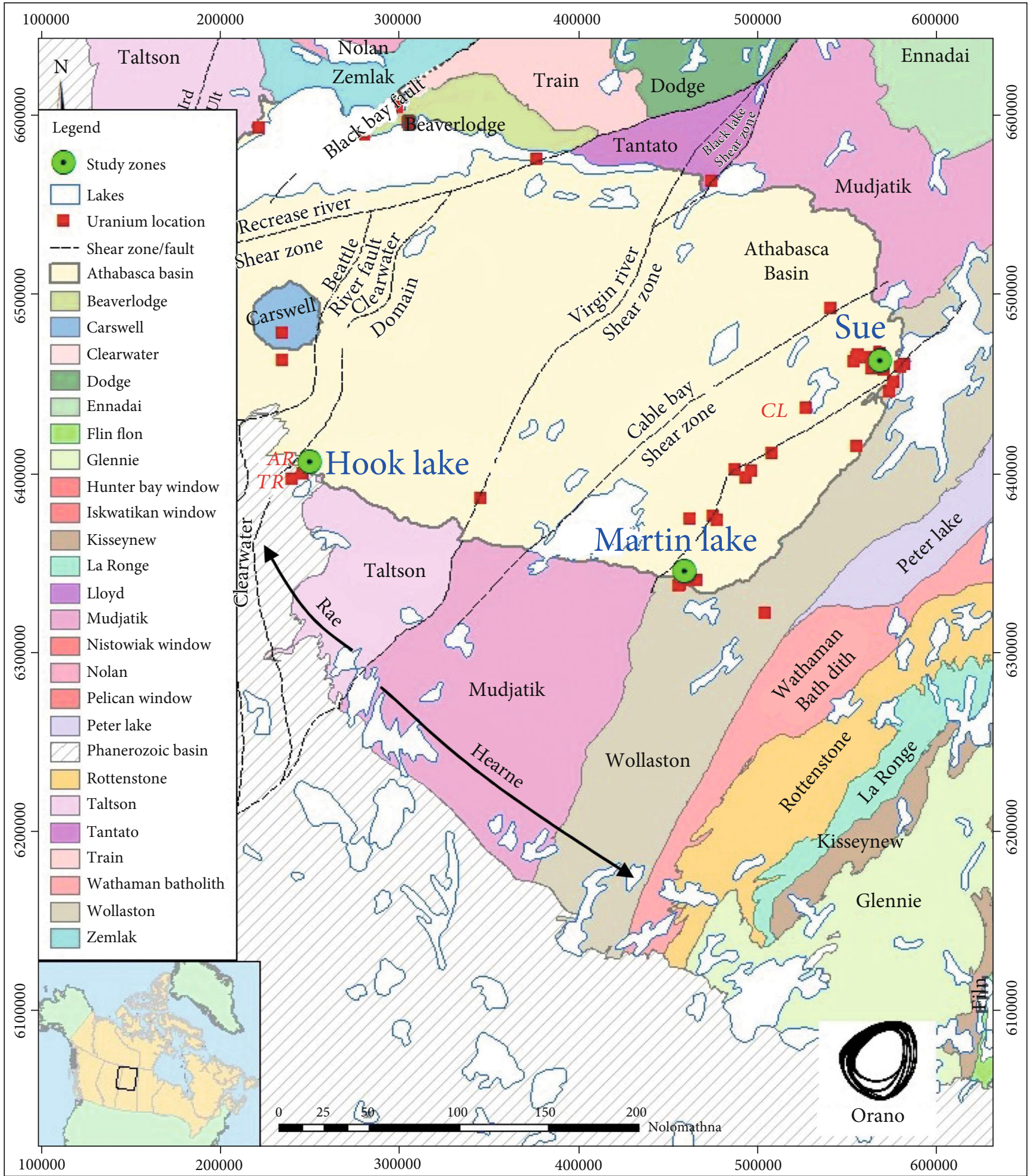

FIgURE 1: Regional geology and location map of the study zones (green dots): Sue deposits, Martin Lake (Tri-Island prospect) and Hook Lake Project (Spitfire prospect). CL: Cigar Lake deposit; TR: Triple "R" deposit; Ar: Arrow deposit.

documented since the 1970 s $[9,10]$, attributing to the structural features the establishment of conduits for mineralizing basinal brines operative as a result of thermal or tectonic events $[5,11-13]$. While in the Thelon Basin, recent work attribute the main regional scale control to a new formed polyphase brittle fault/fracture system that evolved since ca. $1830 \mathrm{Ma}$ [8], in the Athabasca Basin, the main role at the regional scale is attributed to the syn- or post-Athabasca tectonic events responsible for the reactivation of inherited ductile graphite-rich shear zones within the basement originally 
formed previous to $1.8 \mathrm{Ga}$ ([5] and references there in). Improvements to the understanding of the structural control exerted by the graphitic shear zones have been enhanced in the recent years. Basinal brines penetrated into the basement by way of dense networks of microfractures identified from fluid inclusion studies ([5] and references therein). At the time of $U$ deposit formation (ca. 1.46-1.29 Ga), these brines percolated preferentially within the damage zones of some graphite-rich faults, formed during the ca. $1.8 \mathrm{Ga}$ TransHudson orogeny and subsequent retrograde metamorphism and exhumation (ca. 1.8-1.72 Ga) [12]. The circulation of the basinal brines into these structures was enhanced and structurally controlled by the microfracture network at the scale of minerals inherited from earlier brittle reactivation during basement uplift [12] and during the Athabasca synand postbasin infill [5]. Numerical modelling has tested the effects on circulation of basinal brines given (i) coupled compression and fluid flow in a reverse shear/fault system with varying dip angles, preexisting offsets, and various amounts of deformation [11, 14, 15]; (ii) high rheological contrast and strain localization that enhance the development of extensional fracture systems and dilational jogs that represent potential mineralization sites [16]; and (iii) the importance of graphitic zone on the formation of the deposits by reactive mass transport modelling [17]. Although all these recent works have improved the understanding of the role of inherited shear zones on fluid flow and the development of uranium deposits at a micro- and regional-scale, there is still a lack of knowledge about the meso- or deposit-scale structural controls that lead to the present (and potentially predictive) localization of the uranium deposits along a given shear zone. Baudemont et al. and Sheahan et al. [18, 19] present elements for the Sue deposits (Figure 1) to support the hypothesis that at the time of fault reactivation, the nonplanar nature of the reactivated foliation and shear planes mechanically controlled the emplacement and geometry of both foliation-parallel vein systems and associated dilational jogs during compressional tectonics. Hillacre et al. [20] have recently suggested that the major structural trends in the Arrow deposit (Figure 1) followed sinistral Riedel-type system reactivation with multiple brittle reactivations of primary NE-striking shears. In order to provide additional structural constraints, the modes of brittle reactivation of shear zones in the basement of the Athabasca Basin have been investigated.

The present work examines new structural data and deals with (i) the identification of the mesoscale structural traps that lead to the formation of the Athabasca unconformityrelated uranium deposits and (ii) with the understanding of the role and mode of reactivation of the inherited basement shear zones in connection with the circulation of basin brines. Three representative case studies have been selected for a detailed analysis of structures and related uranium mineralization: the Sue deposits (McClean Project) and the Tri-Island showing (Martin Lake Project) in the Eastern Athabasca, and the Spitfire prospect (Hook Lake Project) in the Western Athabasca (Figure 1). Data collection took advantage of recent exploration campaigns conducted by Orano Canada (formerly known as AREVA Resources Can- ada Inc.) and Purepoint Uranium Group, with a strong investment to obtain high quality oriented diamond drill core complemented with borehole images acquired with an acoustic televiewer. This study illustrates the geometrical arrangement of uranium mineralization traps in the studied sites. For simplicity, the term mineralization is used in this article in a broad sense, including from very low grade $(>150 \mathrm{cps} / \mathrm{SPP} \gamma)$, low $(<1.500 \mathrm{cps} / \mathrm{SPP} \gamma)$ to medium grade $(<25.000 \mathrm{cps} / \mathrm{SPP} \gamma)$, to high grade $(>25.000 \mathrm{cps} / \mathrm{SPP} \gamma)$. This work also reveals the importance of the inherited ductile fabric on the development of efficient geometrical traps for mineralization during brittle reactivation supporting the jog hypothesis of $[18,19]$ on the NE-trending structures and brings new information about the structural controls of E-W-trending faults. Finally, we discuss a regional compressional stress field that could have been common to the three studied cases and led to the formation of mineralized dilational jogs and conjugate faults.

\section{Regional Geological Setting and Location of Studied Sites}

The Paleoproterozoic to Mesoproterozoic sedimentary rocks of the Athabasca Basin were unconformably deposited on Archean to Paleoproterozoic basement rocks of the Western Churchill Province [21-23] (Figure 1). The Athabasca Basin was filled by fluviatile clastic sedimentary rocks of the Athabasca Supergroup [21], which is mainly composed of nonmetamorphosed continental quartzose sandstones $[24,25]$. The age of the Athabasca Basin is bracketed between ca. 1720 and ca. $1267 \mathrm{Ma}$ ([26] and references therein). The basement below the Athabasca Basin is subdivided into two lithostructural subprovinces of the Western Churchill province: the Rae Subprovince to the west and the Hearne Subprovince to the east, separated by the Virgin River Shear Zone [27], the Southern extension of the Snowbird Tectonic Zone (Figure 1).

The Hearne Subprovince is divided into the Mudjatik Domain, mainly composed of Archean tonalite-trondhjemitegranodiorite domes and the Wollaston Domain $[28,29]$ that is dominantly represented by Paleoproterozoic metasedimentary sequences (Figure 1). These domains were imbricated within the so-called Mudjatik-Wollaston Transition Zone that corresponds to the foreland of the ca. 1.8 Ga Trans-Hudson orogeny [27]. This transition zone is characterized by a highly strained zone of steeply-dipping anastomosed shear zones that extend over several hundred kilometers along strike. Most of the eastern Athabasca deposits, prospects and showings, including the McClean (Sue) and Martin Lake Projects here studied (Figure 1), are concentrated within the footprint of this transition zone at the intersection between the graphitic bearing shear zones and the unconformity at the base of the Athabasca Basin. Exploration drilling within the WollastonMudjatik Transition Zone focuses on targeting graphitic shear zones (commonly known as electromagnetic (EM) conductors), mostly orientated NE-SW, steeply dipping, that have undergone syn- and/or post-Athabasca brittle reactivation. The Rae Subprovince, West of the Virgin River Shear Zone, is characterized by monotonous orthogneiss dominated by 
granodioritic compositions ("quartz diorite suite"). It ranges in composition as defined by petrography from granitic to gabbroic [30]. Granulite-facies assemblages are preserved in the northwest, retrogressed granulite-facies assemblages in the center and mylonitic, amphibolite-facies assemblages of the Virgin River Shear Zone in the southeast [31]. These rocks were intruded by ca. $1985-1968 \mathrm{Ma}$ plutons of the Taltson magmatic zone and later by the $1843 \mathrm{Ma}$ granite of the Clearwater Domain. The Virgin River Shear Zone was subjected to multiple displacement episodes under ductile, brittle-ductile, and brittle conditions [32]. Uranium deposits reported in the Rae Subprovince are also associated with major fault systems and locally graphitic shear zones like the Patterson Lake conductive trend which, given the recent, major discoveries of the Triple R (Fission Uranium Corp.) and Arrow (NexGen Energy Ltd.) deposits is considered a world class metallogenic province (Figure 1). At present, the Patterson Lake trend contains more than 350 Mlbs of indicated, high-grade $\mathrm{U}_{3} \mathrm{O}_{8}$ resources. The Hook Lake prospect is situated along the northeast extension of the Paterson Lake trend and contains the Spitfire prospect, a high-grade uranium occurrence hosted along a NE-SW steeply-dipping graphite-rich shear zone [33, 34] (Figure 1).

The syn to post-Athabasca tectonic history associated with the formation of the uranium deposits is poorly understood. Reactivated faults show regional to local spatial relationships with stratigraphically and temporally constrained isopach maps, facies changes, and linked paleocurrent data of the basin infill $[5,24]$. The oldest known uraninite in the Athabasca Basin has been dated at ca. 1.6 Ga (U-Pb method, [34]), with the primary uranium mineralization event being interpreted to be in the 1600-1500 Ma period with multiple younger episodes of uranium remobilization occurring until $\sim 0.2 \mathrm{Ga}[23,34-37]$. Far-field continent-wide tectonic events are believed to be responsible for the primary uranium mineralization event, as well as the younger episodes of remobilization $[34,35,37]$.

\section{Methods}

The structural analysis was performed combining drill core observations with structure identification, characterization and orientation using a goniometer and borehole acoustic televiewer (ATV). Continuous core was drilled with NQ (4.7 cm diameter) inclined diamond drilling. Drill core orientation was obtained using REFLEX ACT (Reflex Instruments Ltd.) core orientation devices and structural measurements were hand-picked on drill core and measured with the goniometer, both as described in [38]. Borehole acoustic televiewer data acquisition and processing were done as described in detail by [39] and are summarized here. Structural analysis combining goniometer and ATV of mineralized and nonmineralized structures were identified and characterized. This provided information of barren, mineralized and altered intervals in which the drill core quality and orientation was often poor or null, and within fault zones and fracture corridors. Gamma probing was used to define the mineralized structural intervals. For this study, mineralization has been defined as values exceeding 10 times the background value of $25 \mathrm{cps}$ as determined from nonmineralized sections of the drill holes. Gamma values have been scaled from 25 to $1000 \mathrm{cps}$ in order to emphasize peaks related to weaker mineralization. In high mineralized holes, values were scaled relative to the highest gamma values that could reach several thousands of counts per second. In mineralized holes, values were scaled relatively to the highest gamma values which can reach several thousand cps.

\section{Borehole Acoustic Televiewer (ATV)}

The ATV used for this work is the ABI40GR-2G (and occasionally the QL40-2G, an upgrade from the previous ABI40 used in 2018) full waveform acoustic televiewer. The tool string is approximately $180 \mathrm{~cm}$ long and acquires high resolution amplitude and travel time images for the acoustic signal reflected off the borehole wall along with hole orientation and natural gamma measurements. The acoustic device provides an image representative of the contrast in acoustic impedance between the borehole fluid and wall [40-42]. The resulting log is a representation of the borehole wall as if it were split vertically along magnetic north or the high side of an inclined hole and laid out flat [43] (see examples in [39]). For example, a fracture plane that intersects the borehole wall at a given angle produces a sinusoidal trace on the televiewer $\log [39,44])$.

The ATV is run up hole through zones of interest. The common parameters used are a logging speed of 1.8 meters per minute achieved using $3 \mathrm{~mm}$ vertical resolution and 144 sample azimuthal resolution. The raw tool data is imported into WellCAD ${ }^{\mathrm{TM}}$ software with the images oriented to the high side of the inclined holes. Amplitude and centralized travel time signals are used to identify main core breaks needed for logging, including: lithology changes, contacts, structures and alteration. The apparent measurements are processed to true orientation and corrected for magnetic declination $\left(8.5^{\circ}\right.$ in this case study). The color chart of the reflected amplitude log, which is chosen by the operator, goes from low impedance in blue to high impedance in yellow (Figure 2). Generally, fractures appear in blue colors or black (little to no reflected signal), while silicified rocks or quartz-filled veins appear in bright yellow (high reflected signal). Foliation appears as a high density, tight alternation of blue/yellow strips. Travel time compliments information observed on reflected amplitude mostly for fractures and altered intervals.

\section{Results}

5.1. Structural Controls in the Sue Deposits: McClean Project. Since the discovery of the Sue uranium deposits in 1988-1991 [25] (Figures 1 and 3(a)), the works by [18, 19, 45] and [46] supported by recent numerical modelling by [16] have produced outstanding, interpretative deformation scenarios in which the development of various sets of post-Athabasca brittle faults with intersections with dilational veins and jogs along reactivated Hudsonian shear zones is concluded to have played the major role on fluid flow and uranium mineralization. Mineralizing pre and post-Athabasca deformation events are commonly considered result from far-field east- 


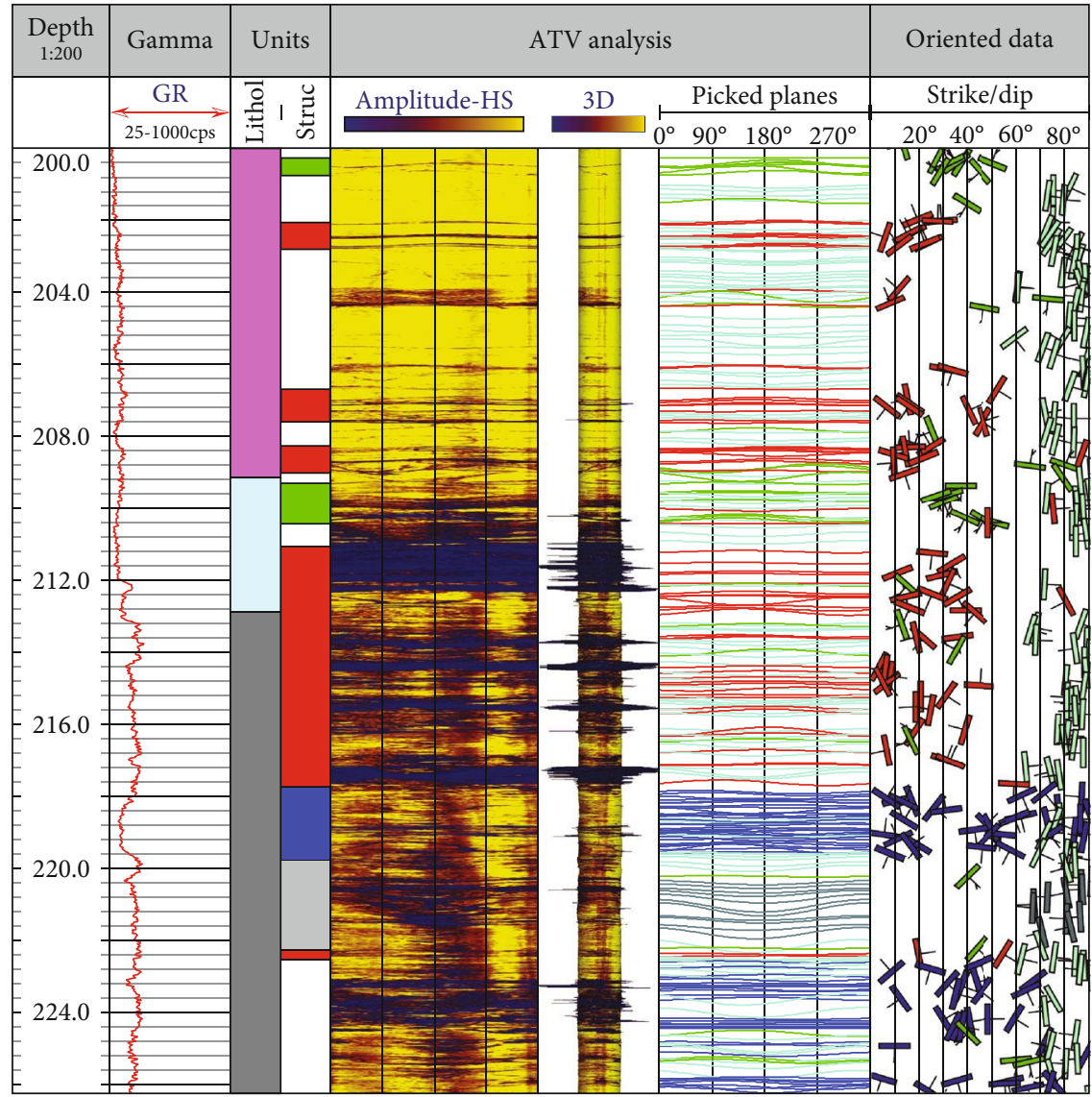

Lithology intervals:

\begin{tabular}{|l|l|}
\hline Granitic gneiss \\
\hline Psammo-pelitic gneiss \\
\hline Pelitic gneiss \\
\hline Graphitic pelitic gneiss \\
\hline Granodiorite \\
\hline Silicified gneiss \\
\hline Pegmatite \\
\hline
\end{tabular}

Structural intervals:

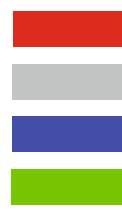

Fault zone

Shear zone

Brecciated zone

Fracture corridor

$\propto$ Fracture
Oriented data:

1 Foliation (S1)

$\Upsilon$ Shear band

$<$ Ductile-brittle fault

$<$ Fault

FIGURE 2: ATV data display as presented in this work. The "Gamma log" column presents the ABI GR gamma probing. The "Litho" column comes from Orano drill hole database (legend is on the side). The "Struct" column displays the interpreted intervals as indicated in the legend on the side. The Amplitude-HS and the 3D correspond to the ATV images as explained in the text. The "Picked planes" are the picked planes for oriented data. The "Oriented data" displays symbols with the measured planes with the true azimuth (north on the top of the page) on a scale of true dip from 0 (left) to $90^{\circ}$ (right) (vertical line grid) of each measured plane. Each value is represented by a structural tick of which the legend is at the side. ATV from drill hole S830A. The structural features picked from ATV images providing true dip and azimuth, following [39], are illustrated in Figure 2.

west shortening which induced reverse reactivation of the preexisting NNE- to NE-trending shear zones [34, 35, 37].

In this section, we present the structural analysis performed from seven inclined diamond drill holes completed during the summer 2016 in the McClean Project (Figure 3(b)). Drill holes targeted basement-hosted mineralization in the lateral extension of the Sue deposits (Figure 3(b)). ATV probing was run in all of the drill holes with the objective to precisely identify the structural controls of basement-hosted mineralization.
The Sue deposits are situated along the western margin of the Archean Collins Bay granitic dome (Figure 3(a)), spatially associated with a dominant $010^{\circ}$-trending lithostructural graphitic pelitic gneiss corridor known as the "Sue Trend", which generally dips steeply to the east. Graphitic pelitic gneiss, pelitic gneiss, and silicified gneiss are the principal types of metasedimentary rocks of the Wollaston Supergroup in the Sue area $[18,19,45,47]$. The regional ore-controlling structure strike NNE $\left(010-015^{\circ}\right)$ and dip steeply to subvertically to the east, and are 
(a)

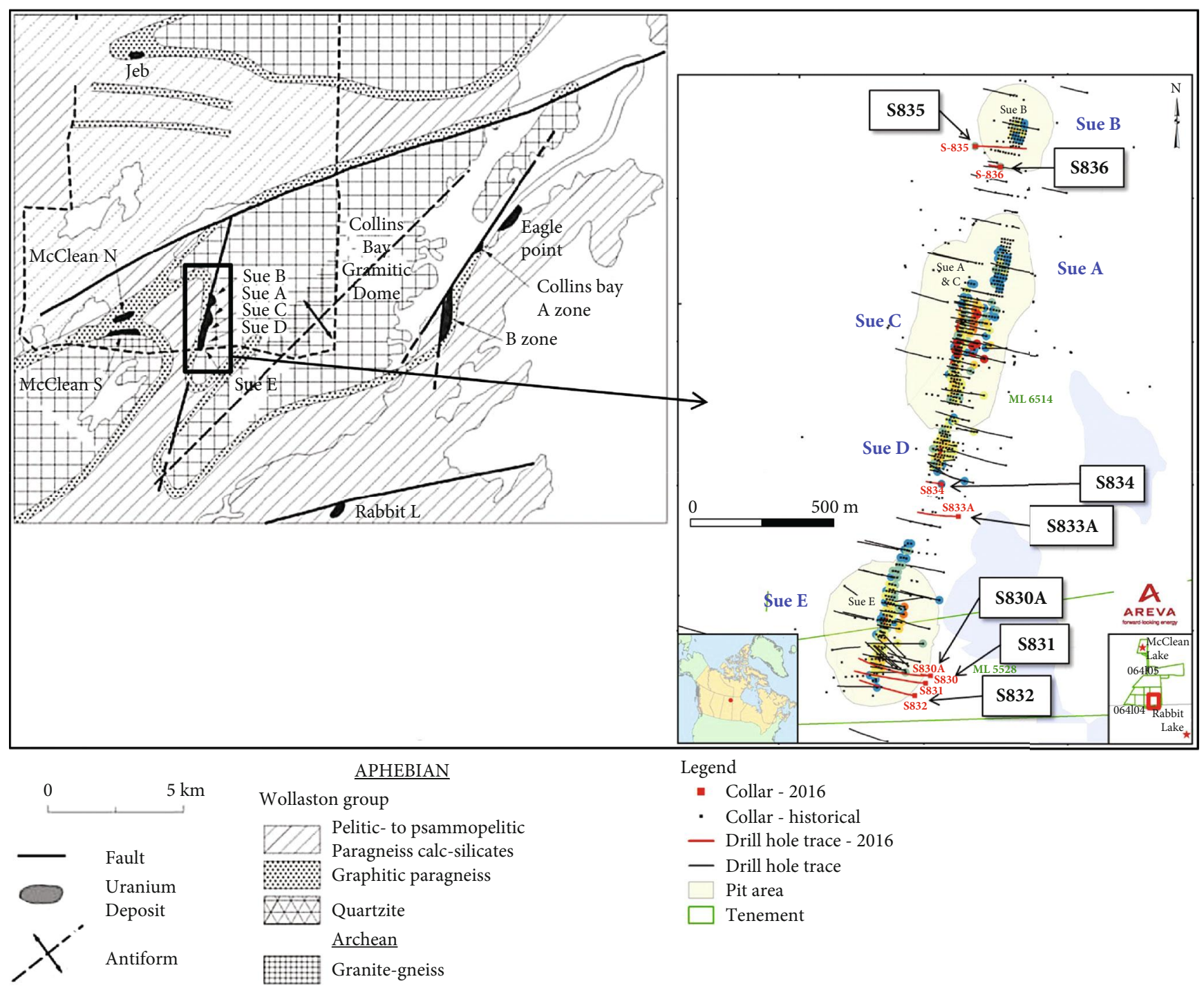

FIgure 3: (a) Regional framework of the Sue uranium deposits, McClean Project (originally from [18]; modified from [48]). (b) Location of the 2016 drilled exploration holes (Orano document).

commonly situated within the graphitic pelitic gneiss. The unconformity was displaced up to $20 \mathrm{~m}$, and a west-directed reverse displacement has been identified [19]. Two additional post-Athabasca fault sets are observed: a NE-SW-trending set $\left(230-240^{\circ}\right)$ that dips steeply northwest, and a NW-SEtrending set $\left(320-340^{\circ}\right)$ that dips steeply to the northeast $[18,19,45,47]$. The Sue Trend uranium mineralization is mainly composed of uraninite as massive nodules, shear vein fillings, and crosscutting extensional veinlets [18, 19, 45, 47]. Host-rock hydrothermal clay alteration pervades and surrounds the zones of mineralization, which are also typically desilicified, variably hematized or bleached, and locally tourmalinized [18, 19, 47].

5.1.1. Structural Analysis and Mineralization Settings. The structural analysis in this site was performed combining borehole ATV data with fresh drill core observations. Identi- fied structures were correlated along sections between drill holes S835-S836, S834-S833A, and S830A-S831-S832.

Drill holes S830A, S831, and S832 were drilled south of the Sue E deposit (Figure 3(b)). They intersected a typical lithological sequence composed of granitic rocks of the Collins Bay dome, graphitic pelitic rocks of the Wollaston Group, and subordinate silicified gneiss, with two major graphite-rich shear zones. None of these holes intersected mineralization. These three drill holes show good structural correlation with well-defined shear zones that steeply dip to the SE and trend N or NNE. Figure 4 shows the correlation of the upper graphite-rich interval (in grey) through drill holes S830A and S832. It also shows the ATV oriented data (right column) and the correlation of the major shear zones observed on drill core. The first significant pattern shown by the ATV oriented data is the homogeneous dip and azimuth of the foliation and shear bands (Figure 4(b)). Foliation 


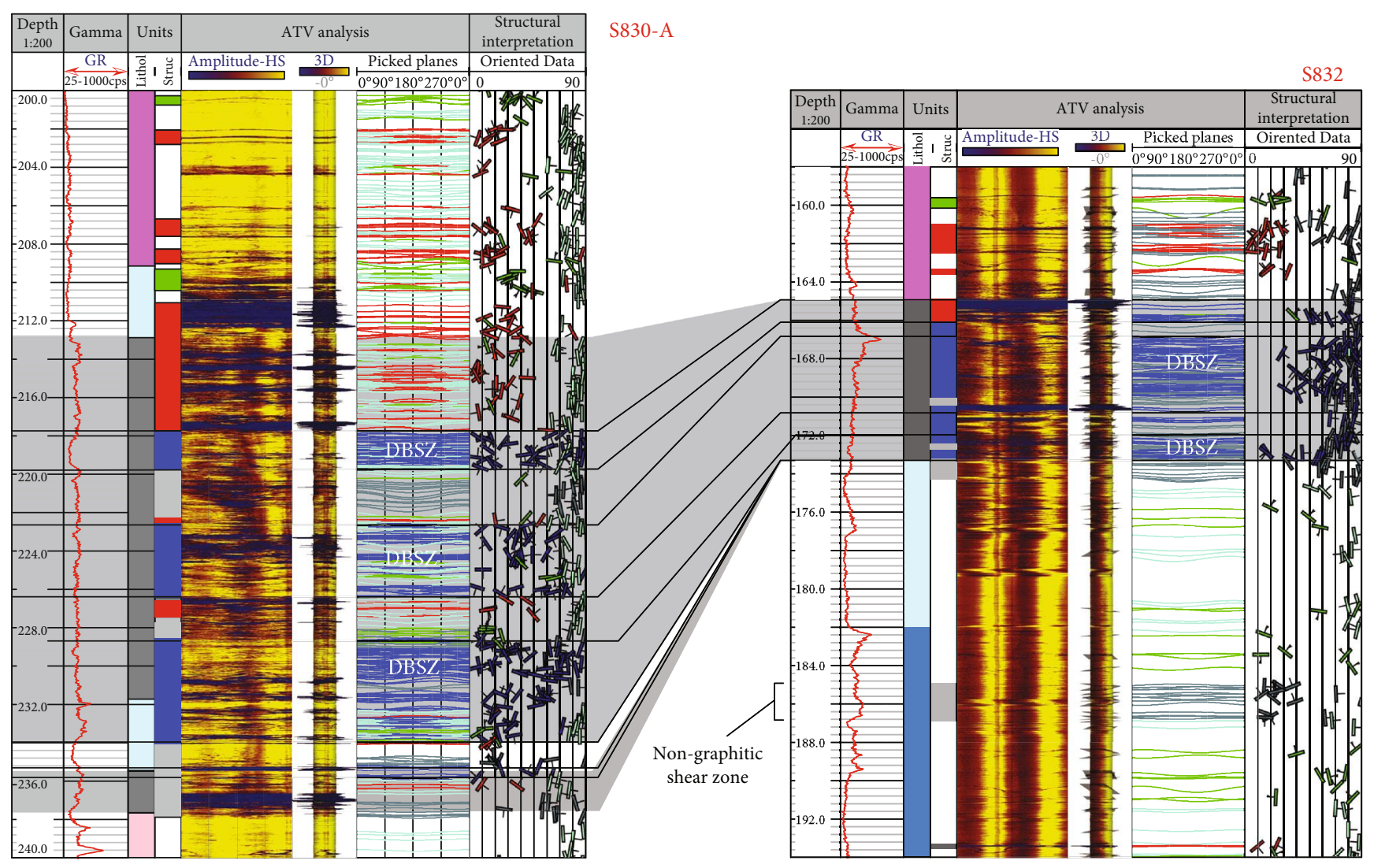

(a)

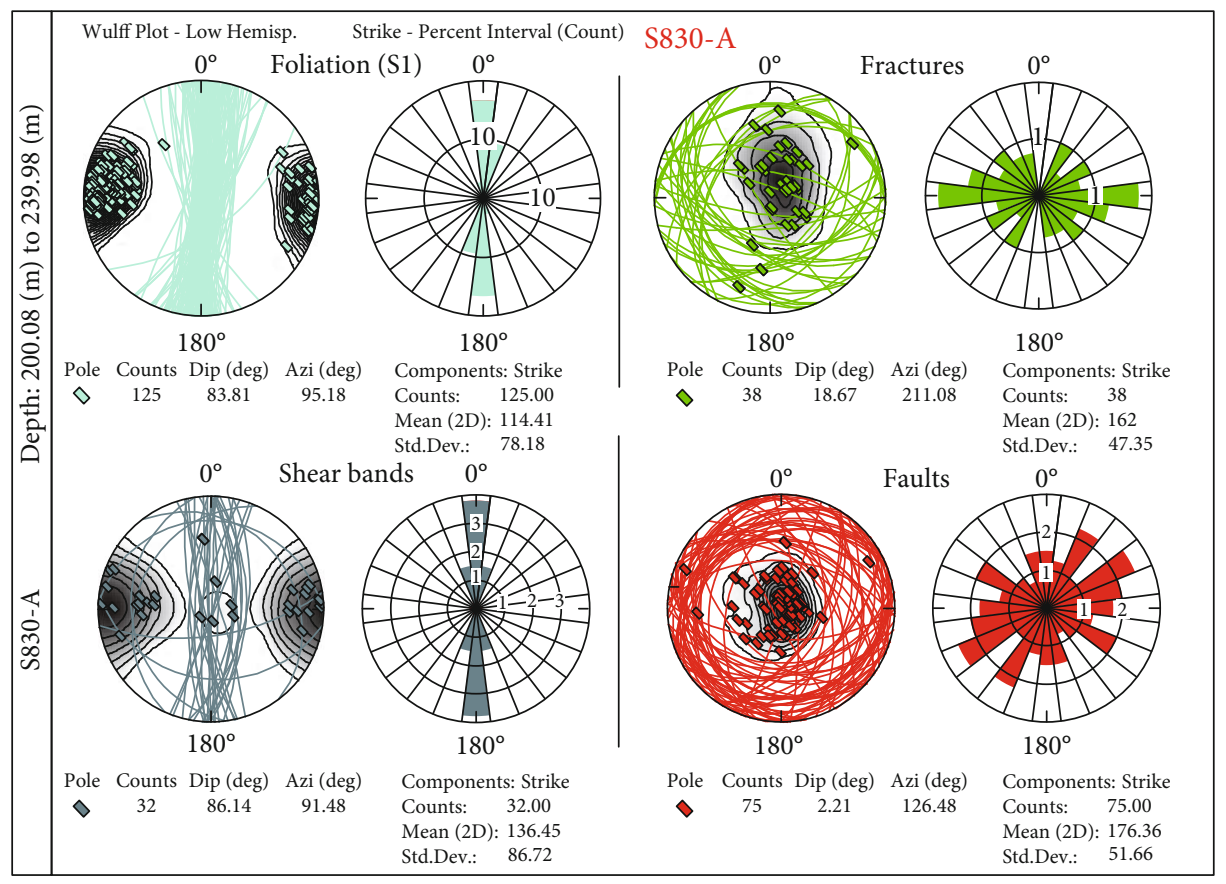

(b)

FIgure 4: Continued. 


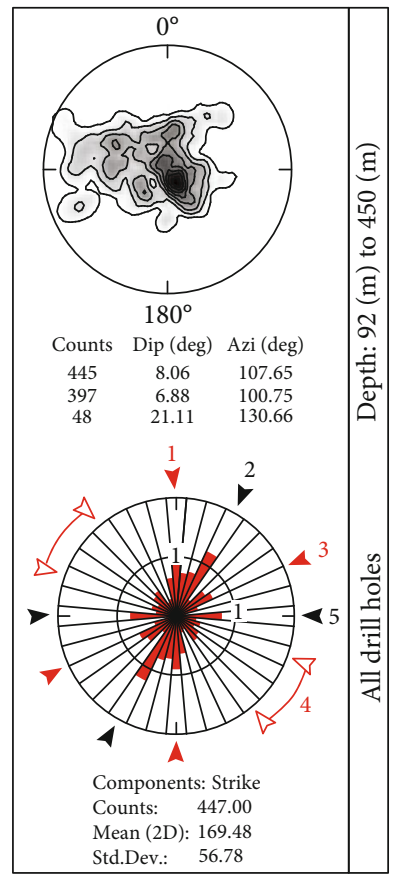

(c)

FIGURE 4: (a) Structural correlation of the upper graphite-rich interval (in grey) and DBSZ (in blue) through the drill holes S830A and S832. (b) ATV oriented data and structural interpretation of the correlated interval. (c) ATV oriented data on stereonets and rosacea plots compiled from all studied drill holes showing the main fault sets with red and black numbered arrows. Legend in Figure 2.

is represented in Figure 4 as bright pale blue picked planes and structural symbols (oriented data). Transposed composite foliation (S1) is dominantly NNE-trending (N000 to N030) and dips subvertical to the east. The homogeneous dip and azimuth are important features that differ in the mineralized intervals of the other drill holes.

Ductile shear zones are preserved, exhibiting deformation patterns as S/C shears and shear bands in the pelitic gneisses and graphitic intervals (i.e., Figure 4(a), S832 at $286 \mathrm{~m}$ ). Shear zones are of two types. Shear zones that exhibit only ductile deformation patterns as shear bands, S/C shears and elongated elements, and, the most common, shear zones that exhibit brittle deformation patterns as cataclastic breccias and secondary fractures overprinting ductile deformation patterns. These last shear or fault zones are commonly known as ductile-brittle shear zones (DBSZ). DBSZ run parallel or subparallel to the main regional foliation (N000 to N030) and are characterized by graphite bearing mylonites that contain centimeters to decametric intervals of cataclastic breccias with reworked angular clasts of pelitic gneiss. Clasts are millimetric to centimetric in size, and are supported by a graphite-rich matrix. In Figure 4, DBSZ are represented as blue intervals in the structural column that group numerous ductile-brittle features, particularly associated fractures represented as blue picked planes and structural symbols in the structural interpretation column.

Fractures are represented in Figure 4 as green picked planes and structural symbols. In drill holes S830A and S832, fractures distribute regularly along drill holes with a dominant E-W orientation and with various sets of secondary fractures with a wide range of strike and dip
(Figures 4(b) and 4(c)). This arrangement and fracture set distribution are common to all the other studied drill holes.

Faults are represented in red in Figure 4. Faults appear all along the drill holes but they are concentrated immediately above the graphitic intervals, i.e., within the hanging wall of the graphite-rich shear zones (Figure 4(a)).

ATV fault analysis allows for sorting the oriented data into five groups (Figure 4(c)): (i) N-S-trending faults, steeply dipping dominantly to the $\mathrm{E}$, matching the main foliation trend; (ii) NNE-SSW-trending faults, dominantly N025- to N035-trending, highly to moderately $\left(80-50^{\circ}\right)$ dipping to the SE; (iii) ENE-WSW-trending faults, dominantly N045N065-trending, moderately to very low $\left(45-10^{\circ}\right)$ dipping both to the north and south; (iv) NW-SE-trending faults, which cover a large range of orientations from N115 to N155trending; and (v) E-W-trending faults, dominantly N080to N110-trending, that offset all the others fractures, including the mineralization.

Drill hole S834 was drilled south of the Sue D pit (Figure 3(b)). This drill hole intersected a low-grade occurrence of disseminated mineralization between 110 and $112 \mathrm{~m}$ (30 cm@461 ppm U). Mineralization occurs within a shear zone in nongraphitic psammo-pelitic gneiss. Moving downhole, the ATV structural analysis identifies (Figure 5(a)): (i) a progressive rotation in the orientation of S1 of approximately $30^{\circ}$ from NNE- to NE-trending and (ii) a progressive lowering of the dip angle through the shear zone from $80^{\circ}$ to $20-30^{\circ}$ (highlighted by the red arrow). These data indicate that the mineralization occurs in a flat-lying shear zone where the foliation turns 
(a)
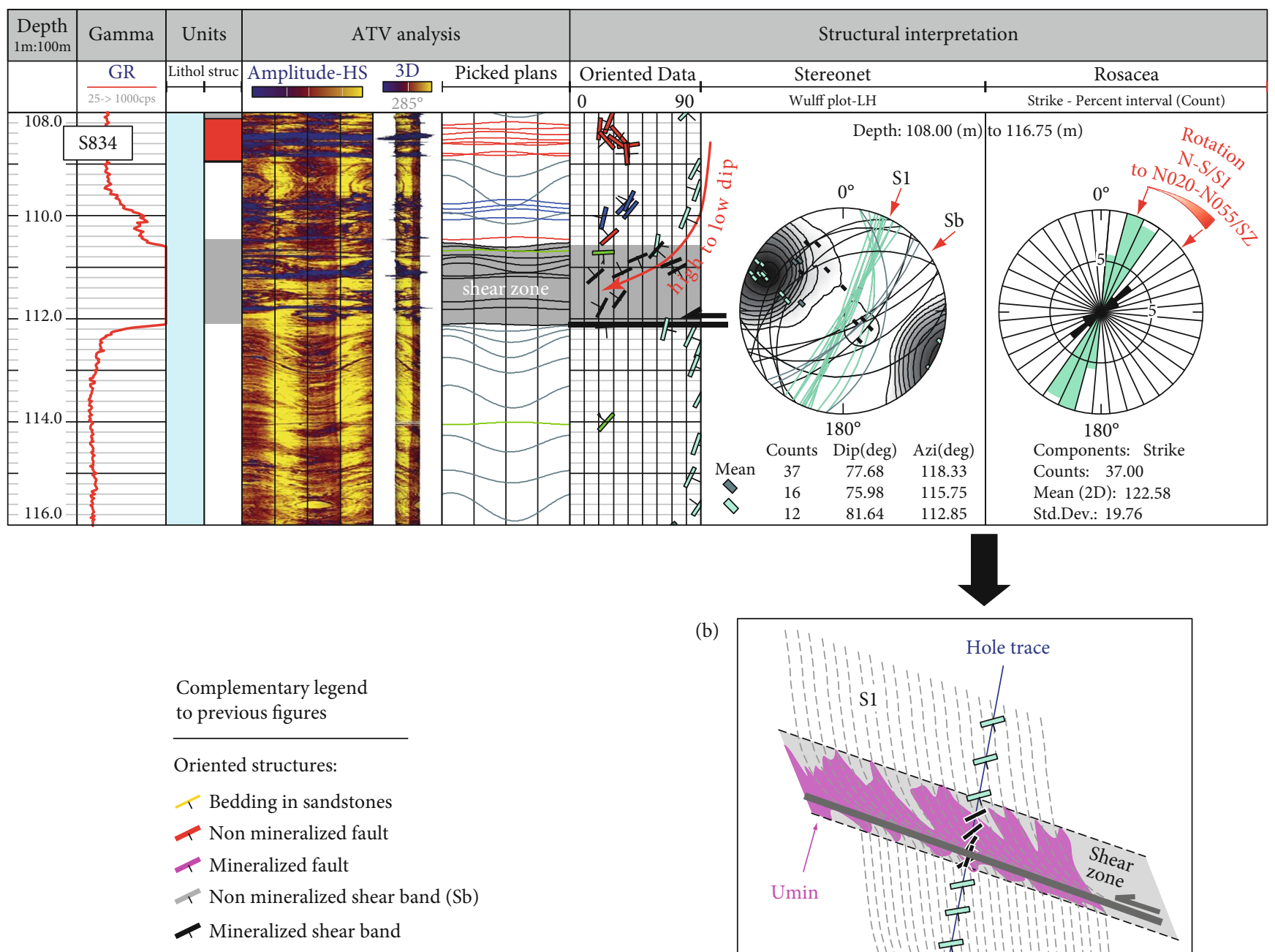

(b)

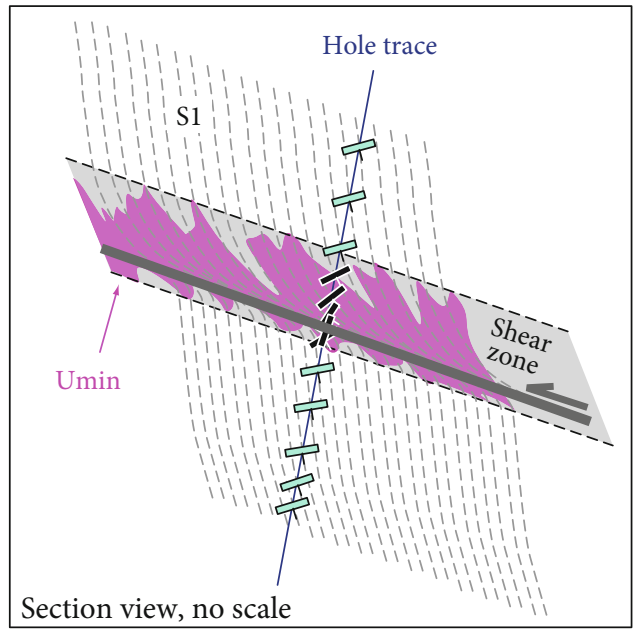

Figure 5: ATV structural analysis of drill hole S834. Disseminated mineralization occurs in a nongraphitic shear zone when it turns from NNE to NE and when dips decrease from highly steeply dipping to low angle dipping. The red arrow indicates the progressive decreasing in dip and the azimuth reorientation. Legend in Figure 2.

from NNE to NE and the dip decreases from steeply dipping to shallowly dipping (Figure 5(b)).

Drill holes S835 and S836 were drilled south of the Sue B deposit (Figure 3(b)). Both holes intersected low-grade mineralization or intervals of anomalous radiometry within the basement. Three settings were identified. The first setting corresponds to local intervals with high gamma peaks above the usual background that are related to local pegmatites within highly strained shear zones. The second setting is formed by very low-grade, disseminated, foliation parallel mineralization ( $>4000 \mathrm{cps}$ ABI GR probe, equivalent to 150 cps SPP $\gamma$ on drill core) spatially related with DBSZ. Mineralization is located at the contact between psammo-pelitic gneiss and graphitic gneiss and coincides with a (reactivated) NNE-trending, steeply dipping DBSZ. The third setting is fracture/vein-related low-grade mineralization $(>8250 \mathrm{cps}$
ABI GR, equivalent to $300 \mathrm{cps} \operatorname{SPP} \gamma$ on drill core) within shear zones. Mineralization is visible in core from drill holes S835 and S836. In drill hole S835, mineralization of this setting 3 was intersected at $225 \mathrm{~m}$ at the top contact of the graphitic gneiss with the psammo-pelitic gneiss (Figure 6(a)) and at $366 \mathrm{~m}$ within silicified psammo-pelitic (nongraphitic) gneiss above the graphitic layer (Figure 6(b)). In this latter case, pitchblende is hosted in oblique, sigmoidal-shaped quartz-vein lenses (fracture-fill), suggesting a crack-seal origin, that typically runs parallel or subparallel to S1 (Figures 7(a) and 7(b)). In detailed view, the pitchblende is located within lenses where the quartz has previously been corroded/dissolved. The crack-seal sigmoidal vein shape and slickensides define NE/60SE reverse dextral kinematics (Figures 7(b) and 7(c)). In the ATV data through the mineralized intervals in drill holes S835 and S836, fractures and S1 
(a)

\begin{tabular}{|c|c|c|c|c|c|c|c|}
\hline \multirow{3}{*}{\begin{tabular}{|c|} 
Depth \\
$1 \mathrm{~m}: 200 \mathrm{~m}$ \\
\end{tabular}} & Gamma & Units & \multicolumn{2}{|c|}{ ATV analysis } & \multicolumn{3}{|c|}{ Structural interpretation } \\
\hline & GR & Lithol Struc & Amplitude-HS & Picked plans & Oriented data & Stereonet & Rosacea \\
\hline & $\rightarrow 1000 \mathrm{cps}$ & & שובו & & 90 & Wulff plot-LH & Strike-percent interval (count) \\
\hline
\end{tabular}

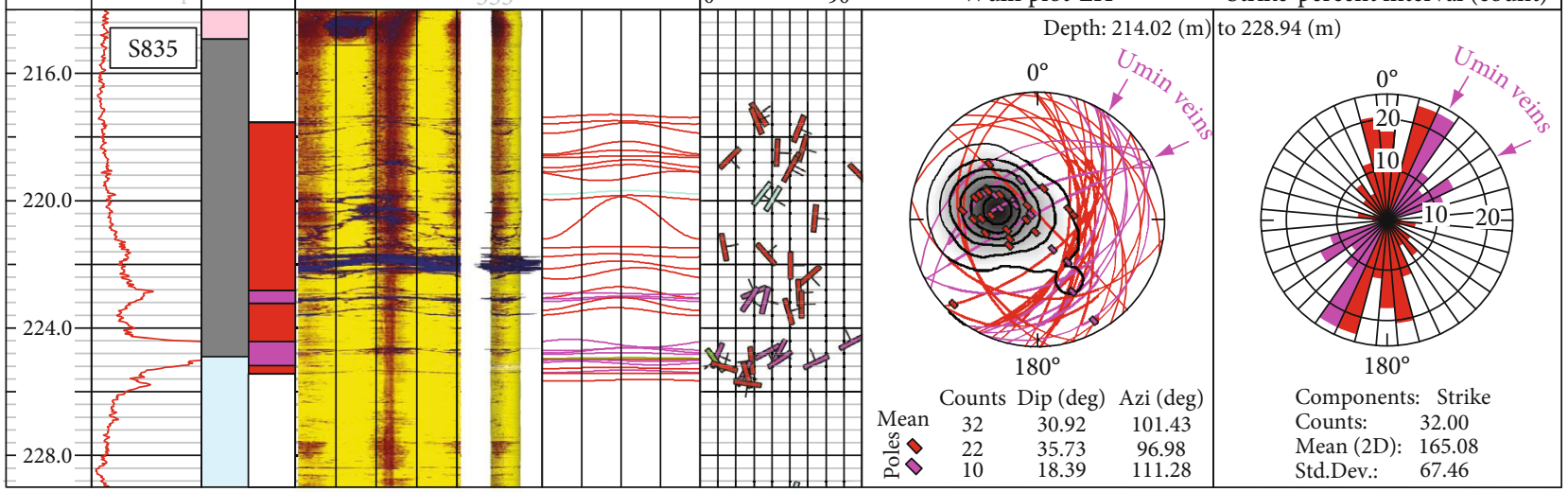

(b)

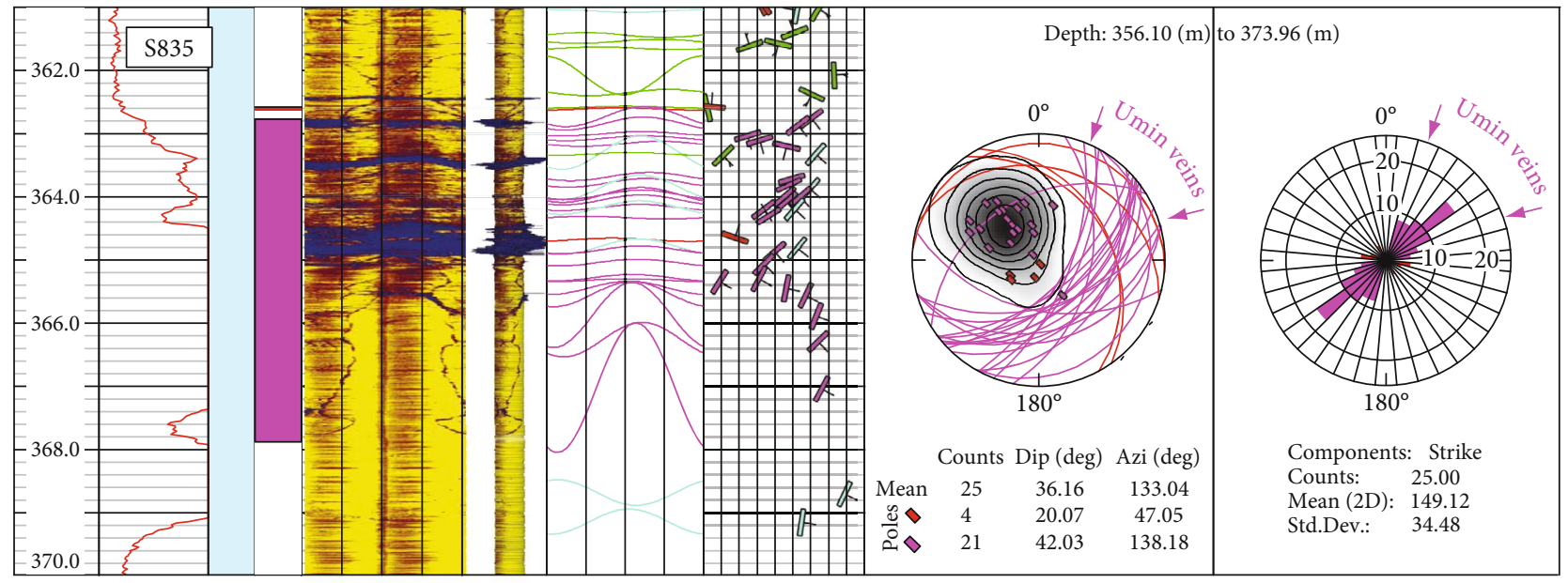

(c)

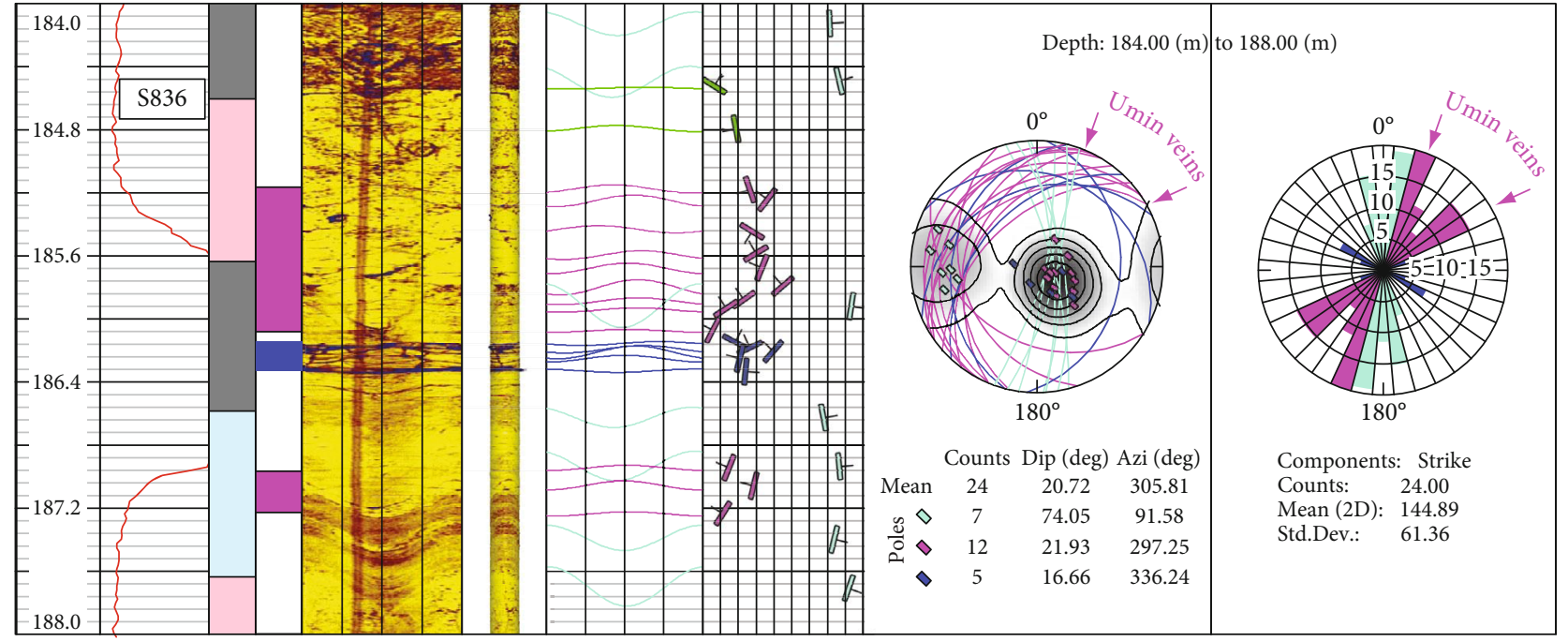

FIGURE 6: ATV structural analysis of the fracture/vein-related mineralization: (a) drill hole S835@225 m, (b) drill hole S835@366 m, and (c) drill hole S836@186 m. Note the bimodal orientation and dip of the mineralized fractures and foliation for all of them. Legend in Figure 2.

display two orientations (Figure 6): NNE (N010-N020) and NE (N045-N060), and shallower dips, the same as observed in drill hole S834 (Figure 5(a)).

The composite foliation observed at the Sue deposits is extensively described in $[19,48]$. Although kinematic indicators of reactivation in DBSZ are poor in our observations,
post-Athabasca reverse dextral reactivation has been inferred from local offsets at the unconformity by $[18,19,48]$. Kinematic indicators on NE-SW-trending fractures indicating reversal dextral to sinistral kinematics are described in [18, 49] and [19]. NW- (to NNW-) trending faults show a dominant late normal component $[19,49]$. 
(a)

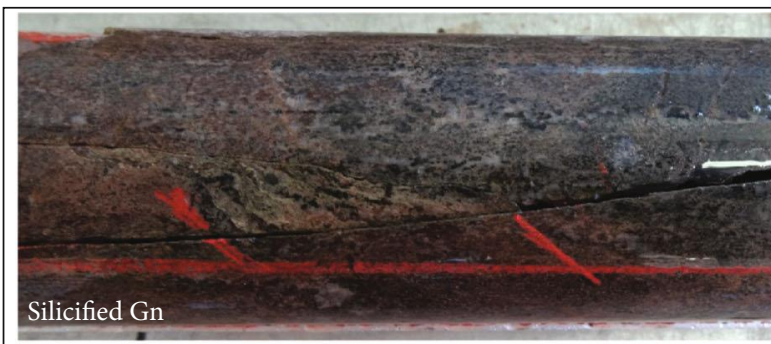

(b)

(c)
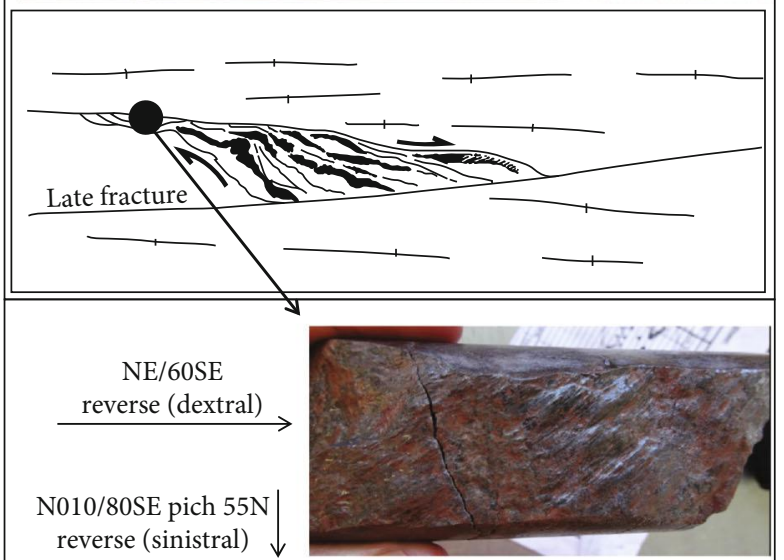

(d)

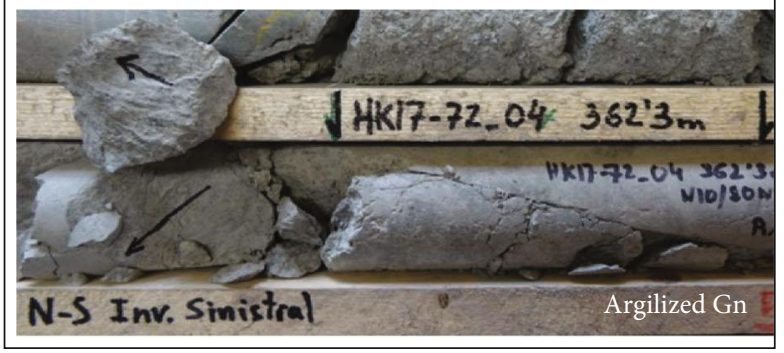

Figure 7: Kinematic indicators on drill core samples from Sue (a, b, and c) and Spitfire (d), illustrating (a) crack-seal mineralization in drill hole S835@366 m. (b) Interpretation of (a): pitchblende is hosted in oblique/sigmoidal quartz veins lenses (crack-seal) that run parallel or subparallel to the foliation. (c) Slickensides. Reverse dextral kinematics is deduced from (a) and (c). (d) Slickensides on drill core sample from Hook Lake (HK17-72@362.3 m) indicating reverse sinistral motion.

5.1.2. Structural Interpretation and Controls on Mineralization. Nonmineralized intervals in drill holes are characterized by a homogeneous steep dip and a N-S strike of the foliation and DBSZ (i.e., global strike and dip of the Sue trend), with local NNE-striking shears (Figure 4(b)). This is an important feature that differs in the mineralized intervals of the studied drill holes S834 S835 and S836 (Figures 5 and 6). Mineralized intervals are characterized by two types of mineralization: disseminated and fracture/vein-related. When mineralization occurs, it is associated with foliation and shears that rotate from NNE (N020) to NE (N055) and with a shallowing of the dip from subvertical to moderate/low-angle to the SW and NE (Figure 8(a)). Mineralized veins are associated with intervals within which fractures display a fan of orientations from NNE to ENE, with dominant moderate to low dips to the SE (Figure 8(b)), or a bimodal orientation NNE (N010-N020) and NE (N045-N060) with moderate to low dips to the NE
(Figure 8(c)). Both configurations of mineralized veins exhibit moderate to low-angle dips.

The shallower dip and the bimodal azimuth in the mineralized intervals can be interpreted as the intersection between distinct NNE and NE fracture sets or as Riedel "en-échellon" structures $[18,19,48]$. However, the ATV analysis shows the change from steep to shallow dips and from NNE to NE azimuths both occur progressively (i.e., Figures 5 and 6). As such, changes in both strike and dip are interpreted as related to local bends of shear zones, both laterally and vertically, along the trace of the Sue trend (Figure 8(c)). Reverse brittle reactivation of DBSZ has been argued by [18] and [19]. The reverse motion in the brittle regime on such a fault bends would have produced extensional crack or jogs where dips are shallower (Figure 8(c)). To open such a dilational jog when the azimuth turns from $\mathrm{N}$ to $\mathrm{NE}$, reverse motion had to be right-lateral (dextral). Dextral kinematics is coherent with the observed crack-seal sigmoidal vein shape on drill core (Figure 7) and was already observed by [18, 19, 49] on NNE-SSW faults. This correlation strongly supports the genetic relationship between fault bends and the development of dilatational jogs in reversal dextral tectonic reactivation as geometric traps for fluids to produce mineralization.

5.2. Structural Controls in the Tri-Island Trend: Martin Lake Project. The Martin Lake Project lies in the WollastonMudjatik Transition Zone (Figure 1). Along the Martin Lake graphitic conductor, a mineralized zone was discovered in 2015 and drilled during 2016 and 2018. Mineralization is hosted within the so-called Tri-Island graphite bearing shear zone which is oriented ENE-WSW in the area of the discovery (Figure 9(a)). Postbasin reactivation of the Tri-Island trend is supported by the offset of the unconformity observed ahead of the graphitic shear zone (Figure 9(b)).

Seven drilling fences were explored between 2015 and 2018 with the completion of twenty-five cored drill holes (Figure 9). Sixteen drill holes were studied for this work with the focus on the interpretation of structural controls on mineralization. Oriented data in all holes was collected by the Orano geologists using a goniometer and provided in true azimuth and dip of observed structures. Acoustic Televiewer (ATV) was run along a $240 \mathrm{~m}$ thick interval in drill hole ML140 (Figure 10). Various cross sections and maps were created from drill hole logging (logging from Orano geologists) as well as from structural data by the authors.

5.2.1. Structural Analysis and Mineralization Settings. The analysis of ductile patterns on drill core only allowed for the simple differentiation of a dipping penetrative foliation (possibly transposed foliation events), shear zones (including DBSZ as described above in the Sue deposits), and large scale folding of the so-called regional D2/S2 event $[50,51]$, here noted as undifferentiated D1/S1. Oriented data of the $\mathrm{D} 1 / \mathrm{S} 1$ foliation (S1) and inferred transposed shear zones is here used for the structural analysis following [39]. Figure 9(c) presents the oriented data of the foliation (S1) and transposed shear zones from the barren zone to the west moving into the mineralized zone to the east. These oriented data show, from west to east, a noteworthy change in the 
(a)

(b)

(c)

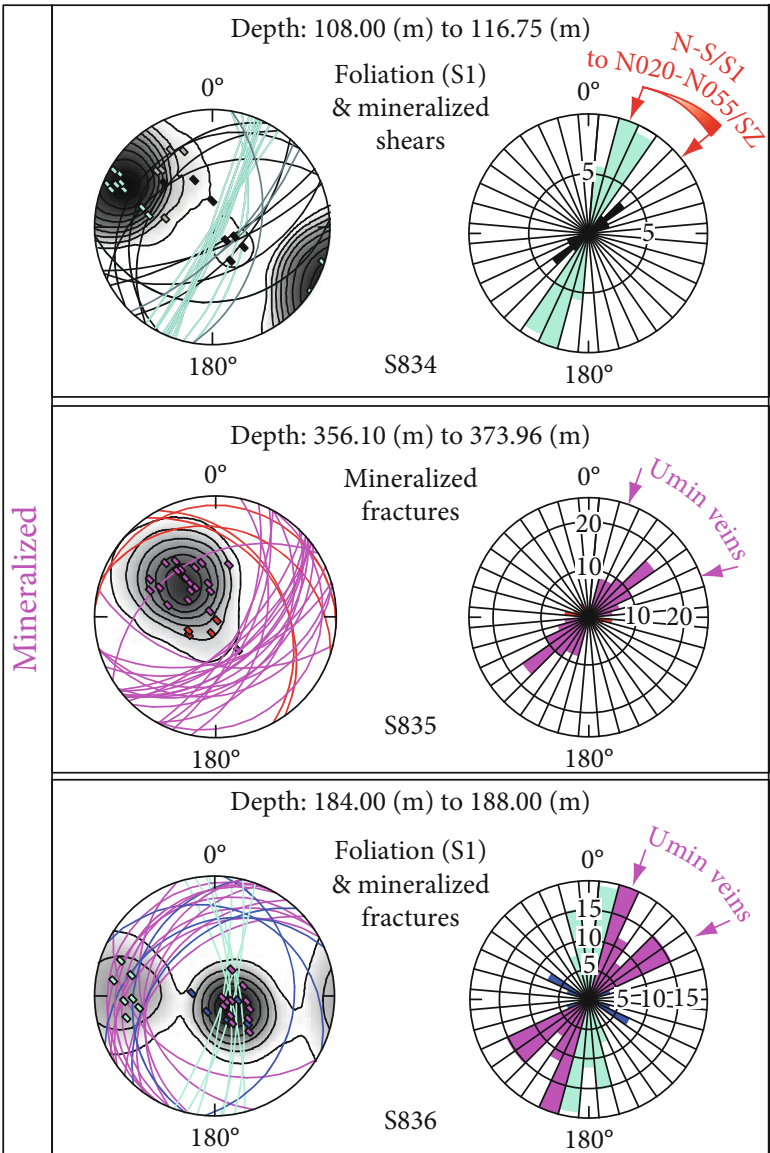

(d)

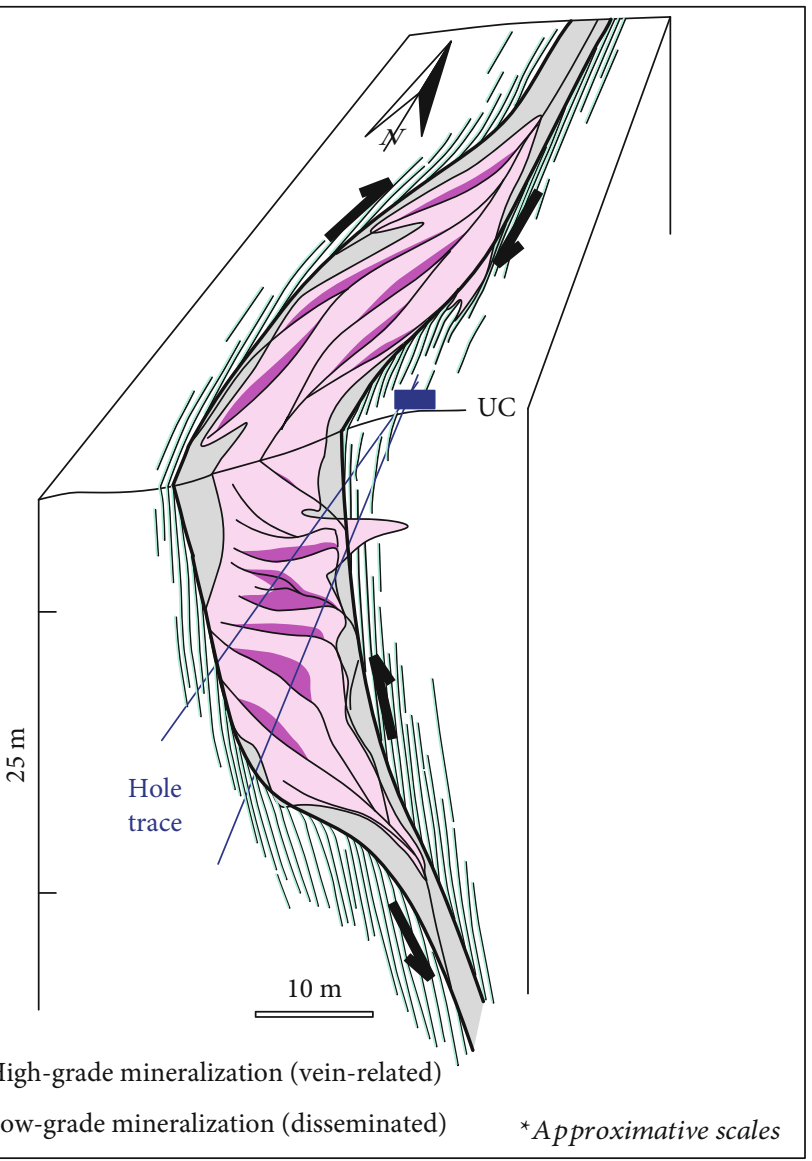

FIGURE 8: ( $a, b$, and c) ATV oriented data analysis from the mineralized intervals in drill holes S834, S835, and S836, respectively, showing the arrangement of foliation and mineralized shears and fractures/veins. (d) Schematic drawing of the structural interpretation for mineralized intervals. Explanation in the text.

S1/shear zone patterns from the same steeply dipping south sense of dip to a progressively conjugate north and south sense dip (synthetic to the south and antithetic to the north). Note that plane poles progressively span from the north to the south in the stereoplots when moving from west to east. The structural analysis of the ATV data from drill hole ML137 shows the same stereonet configuration (Figure 10); within the shear zone of conjugate, north and south dip sense (synthetic to the south and antithetic to the north) of the foliation/shears is present. Note that plane poles progressively span from the north to the south in the stereonets when moving downhole.

Brittle deformation in the studied drill holes was recorded by: (a) the offset of the unconformity, most often reverse and related to the reactivation of ductile shears. The clearest offset of the unconformity occurs along the contact between the silicified gneiss in the hanging wall and the pelitic/graphitic unit (Figure 9(b)). This faulted contact is defined by strong well-sealed, nonmineralized quartz breccia. (b) The N-S-trending (NNW-SSE to NNE-SSW), rightlateral strike-slip offset of the Tri-Island trend. These strikeslip faults are common high frequency and mapable in the area (Figure 9(a)), systematically offsetting the Tri-Island trend. N-S faults are characterized by cataclastic breccias with strong clay alteration formed by muscovite and proba- ble illite. (c) Faults that involve both the basement and the basin sandstones with minimal (meter-scale) unconformity offset. These faults are inferred to be reactivated basement shears which propagated upwards into the sandstones. Three main sets of this type of faults were identified: a NW-SE-trending set, a NE-SW-trending set and a main E-W-trending (WNW-ESE to ENE-WSW) set. This last set of E-W faults most often reuses foliation or DBSZ shear zones and is the main mineralized fault set. All fault sets display strong clay alteration which often overprints cataclastic breccias.

Mineralization was intersected in several drill holes. Here below, we synthesize mineralization on the bases of the characteristics it presents in two drill holes in which it is faultrelated, ML-134 and ML-141 (location in Figure 9(a), cross section $b_{6}$ ).

In drill hole ML-134 the mineralized interval extends from 205.3 to $249.2 \mathrm{~m}$. This interval includes, from top to bottom, (i) disseminated low-grade mineralization $(<1.500 \mathrm{cps} / \mathrm{SPP} \gamma)$ with three small intervals of mediumgrade mineralization $(<25.000 \mathrm{cps} / \mathrm{SPP} \gamma)$ and (ii) a principal interval of high-grade mineralization $(>25.000 \mathrm{cps} / \mathrm{SPP} \gamma)$ up to $30 \% \mathrm{U}$ from probing calculation (Figure $11(\mathrm{a})$ ). The disseminated low-grade mineralization occurs within an interval of graphitic gneiss with strong bleaching and weak to 
(a)

(b)

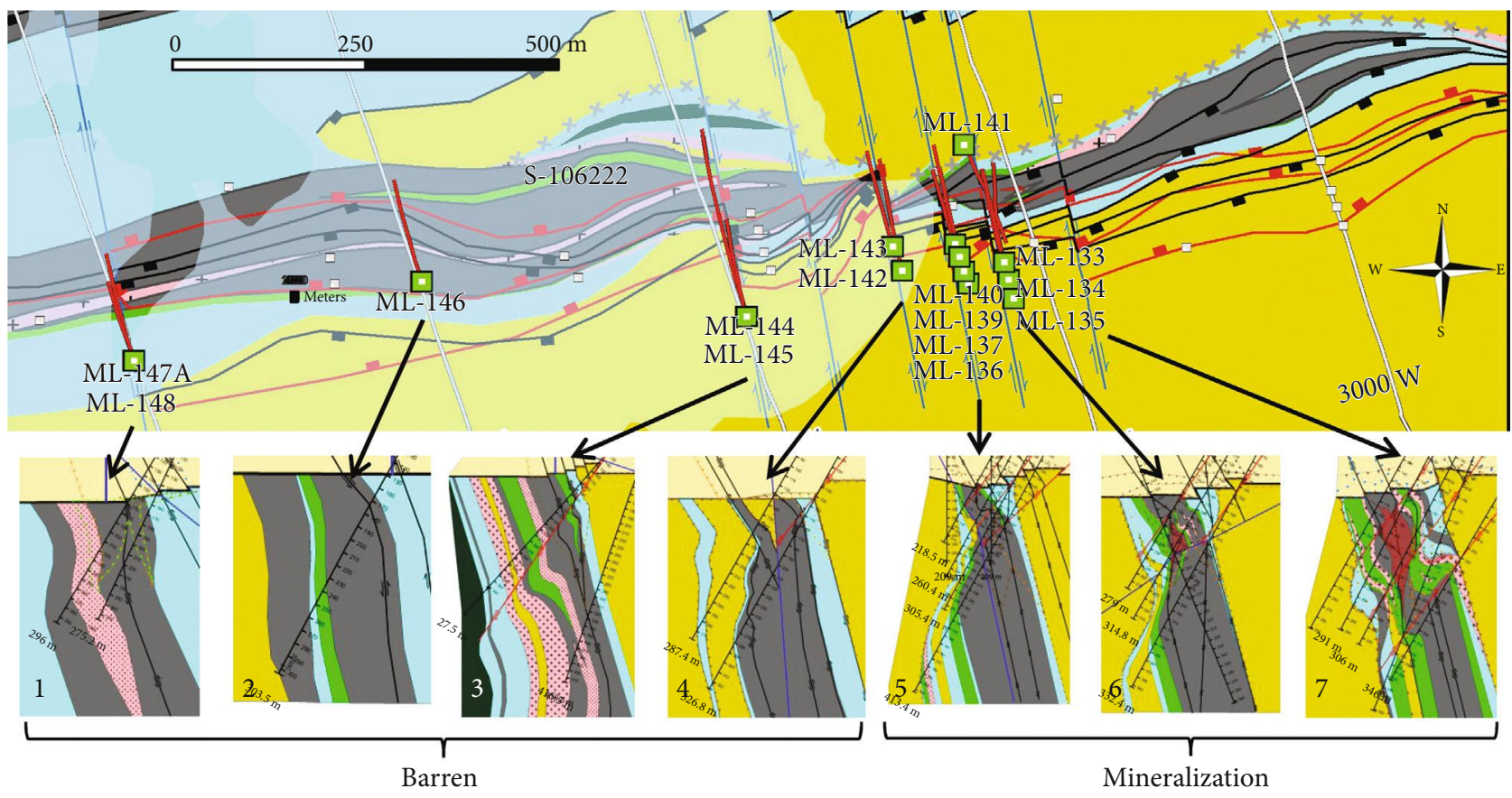

(c) ML147A-148 S1 ML146 S1

ML143-142 S1

ML140-136 S1

ML141-133 S1

ML123-119 S1
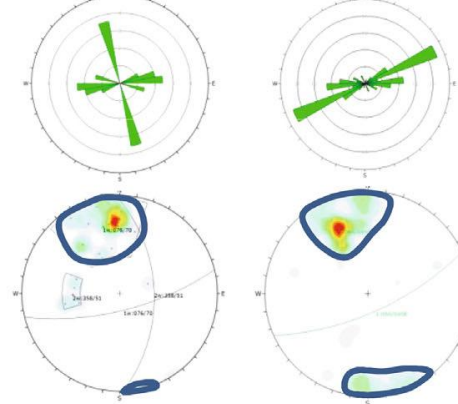

S1
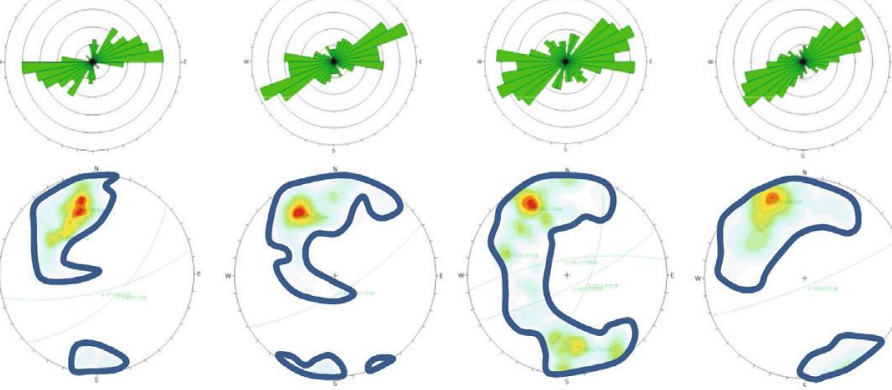

L

1

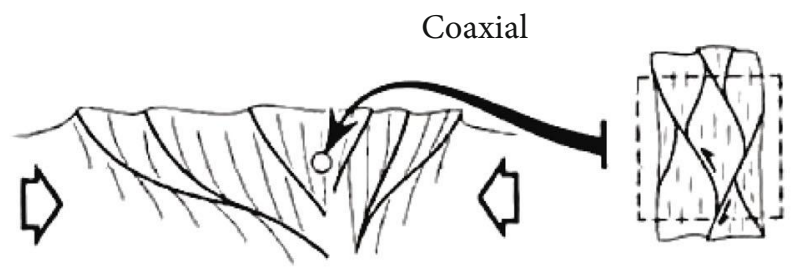

From Gapais et al. (1987)

(d)

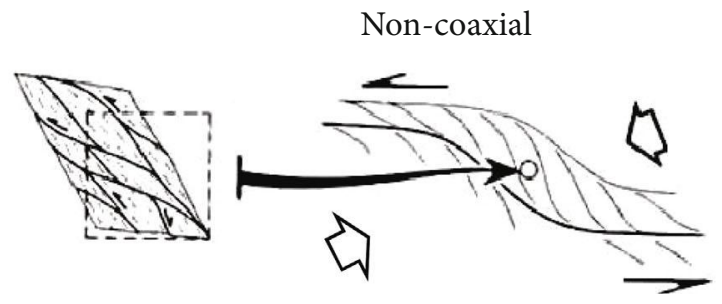

Coaxial

Silicified gneiss

Pegmatites

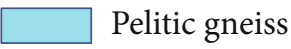

프 Faults

Graphitic gneiss

Figure 9: Location of the revisited drill holes (a) and sections (b) along the Tri-Island conductor, Martin Lake Project. Orano's map and sections. (c) Rosacea and plane poles stereoplots (contours) of oriented data of foliation (S1) (Orano's database) and inferred transposed shear zones from the barren far west moving into the mineralized zone (red) to the East. (d) Cartoons showing the 2D shear zone pattern resulting from noncoaxial versus coaxial deformation.

moderate clay alteration (muscovite/illite). Microfractures filled by secondary graphite (or dark chlorite) are frequent (Figure 11(b)). The uppermost interval of medium-grade mineralization at $209.8 \mathrm{~m}$ appears spatially related with a $15-20 \mathrm{~cm}$ thick fault zone (Figure 11(c)). Fault-related fractures are subparallel to foliation and oriented E-W. Uranium 


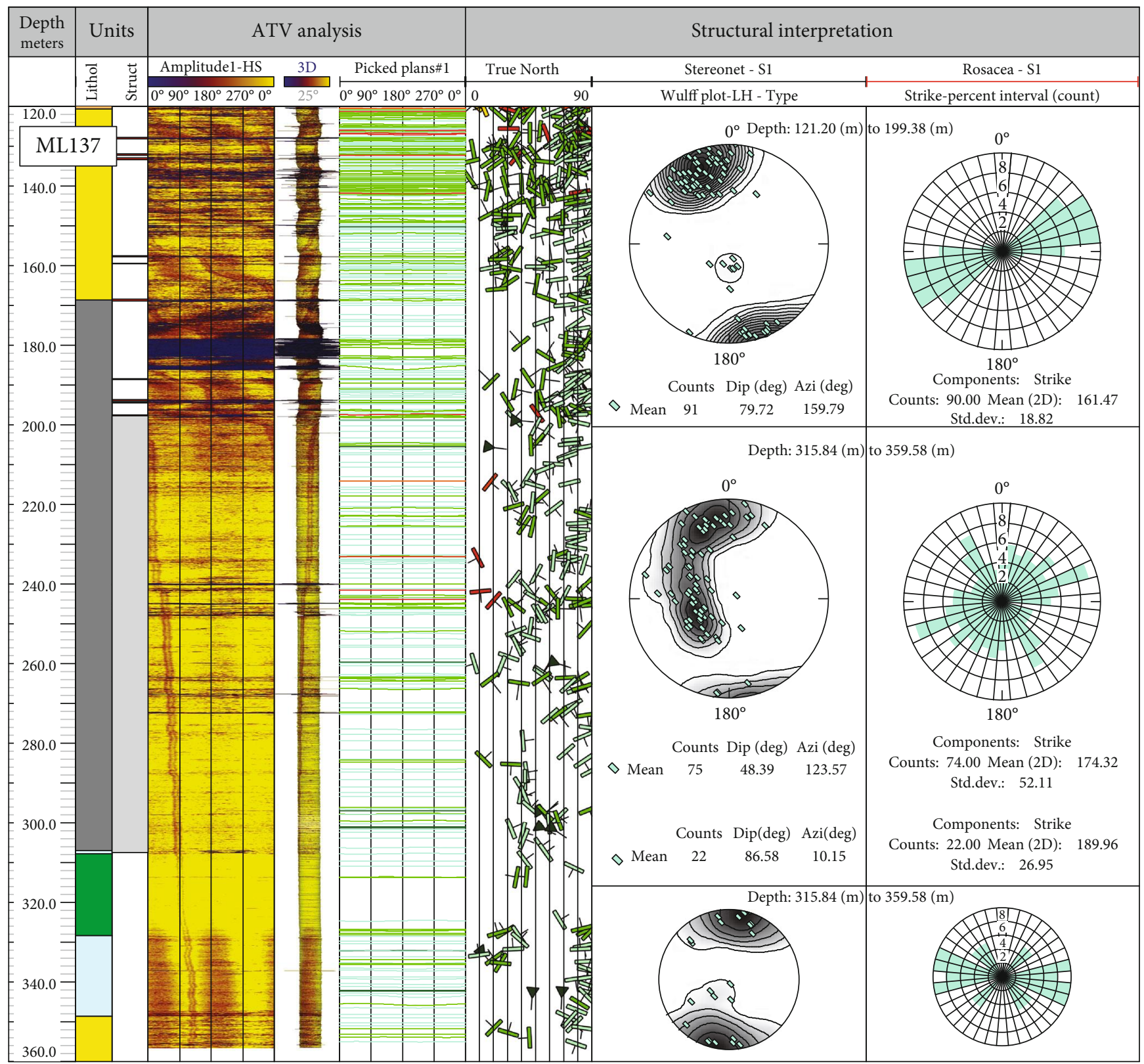

Figure 10: ATV data structural analysis from drill hole ML-137 showing the arrangement in conjugate shear zones. Note that, within the shear zone, poles span from the north to the south of the stereonets. Legend in Figure 2.

nodules within the fault zone are rimmed with limonite. The intermediate and lower intervals of medium-grade mineralization (217 to $217.3 \mathrm{~m},<21.630 \mathrm{cps} ; 221.4$ to $221.8 \mathrm{~m}$, $<11.700 \mathrm{cps}$ ) are limonite-related oxidation fronts that seems to infiltrate along foliation (Figures $11(\mathrm{~d})$ and $11(\mathrm{e})$ ). The highest grade and main mineralization interval, between $223.5 \mathrm{~m}$ and $227.9 \mathrm{~m}$, is also characterized by limonite oxidation. The mineralization in this last interval evolves down hole from massive to disseminated with a transition zone of dark chlorite (Figures 11(f). The basal contact is abrupt and interpreted as faulted. The fault occurs between 227.3 and $227.9 \mathrm{~m}$ and shows the highest radiometry with up to $17.000 \mathrm{cps}$ in this drill hole (Figure 11(g)). Two other satellite faults with clay alteration and mineralization are also visible (i.e., at $222.4 \mathrm{~m}$, Figure $10(\mathrm{~h})$ ). In both faults, clay alteration is associated with bleaching which overprints and postdates mineralization.

Drill hole ML-141 intersected the bottom of the mineralized body less than $2 \mathrm{~m}$ apart from drill hole ML-134 between 216 and $221 \mathrm{~m}$. Mineralization is high-grade, dark grey, and fracture-related and preserved from any oxidation. Mineralization at $216 \mathrm{~m}$ is related to strong clay alteration (sericite flakes within a probable illite matrix) and consists of two massive centimeter-scale pitchblende veins; one is parallel to foliation (Figure 12(a)) while the other crosscuts foliation obliquely (Figure 12(b)). Both veins are associated with a halo of mineralization invading the host rock. Mineralization at $220 \mathrm{~m}$ is high-grade, vein-related (Figure 12(c)) and associated with a cataclastic-corrosion wear breccia facies (Figure 12(d)). This breccia is formed by chaotic, subangular 


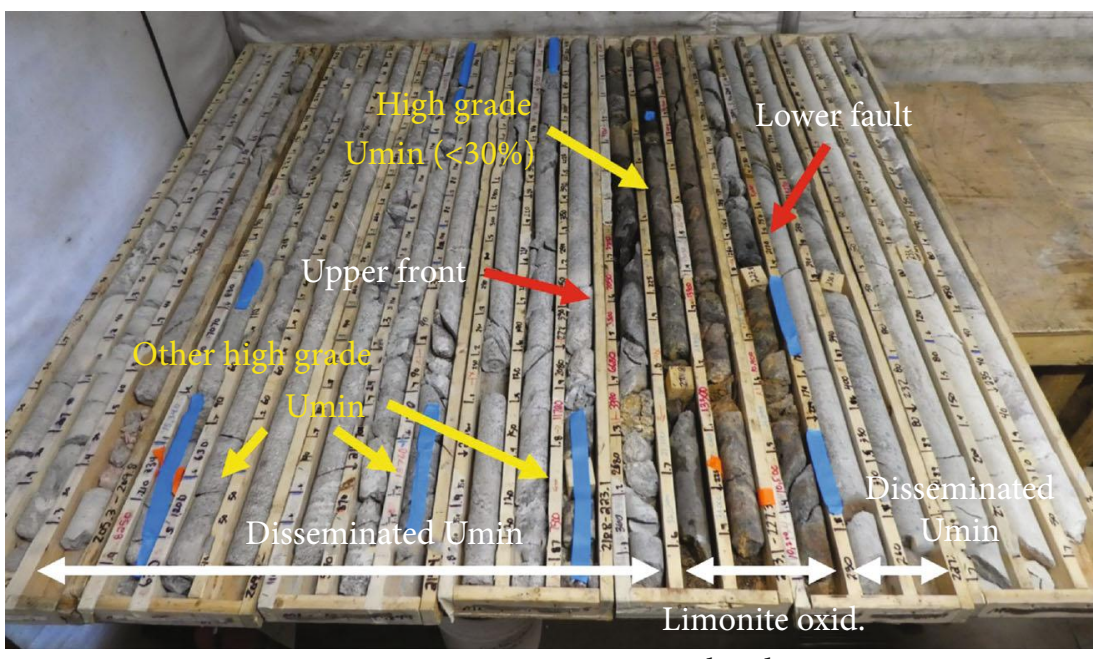

related Umin

(a)

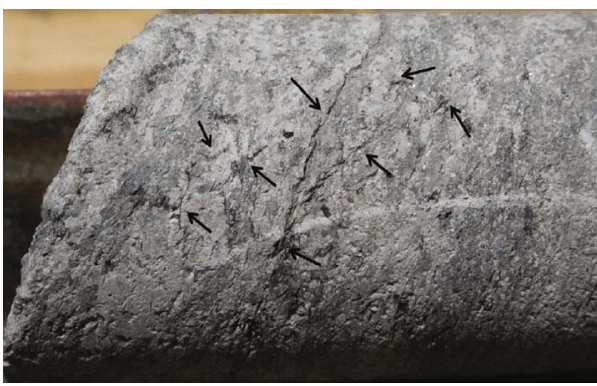

(b)

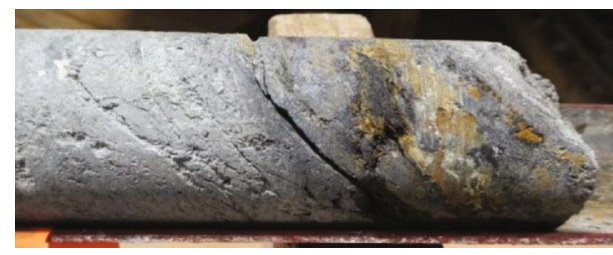

(c)

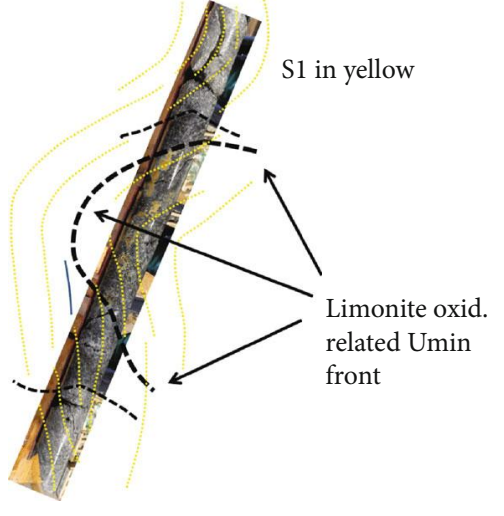

(d)

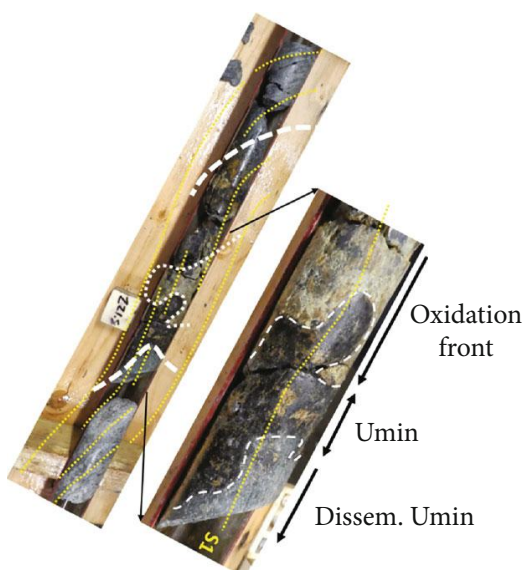

(e)

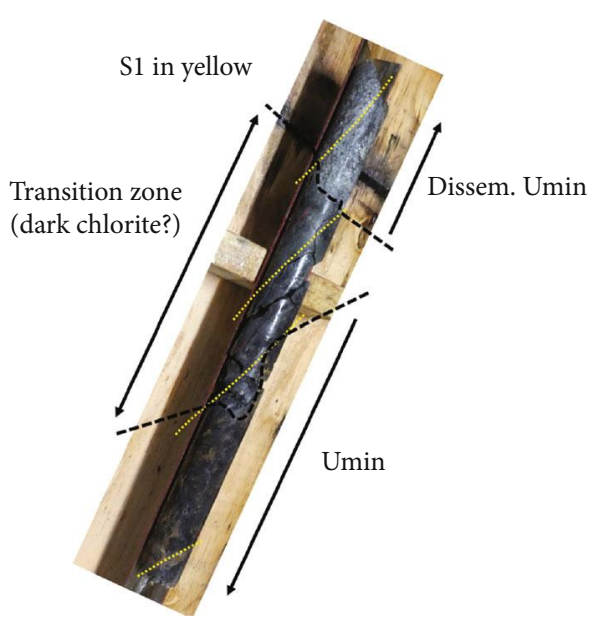

(f)

Figure 11: Continued. 


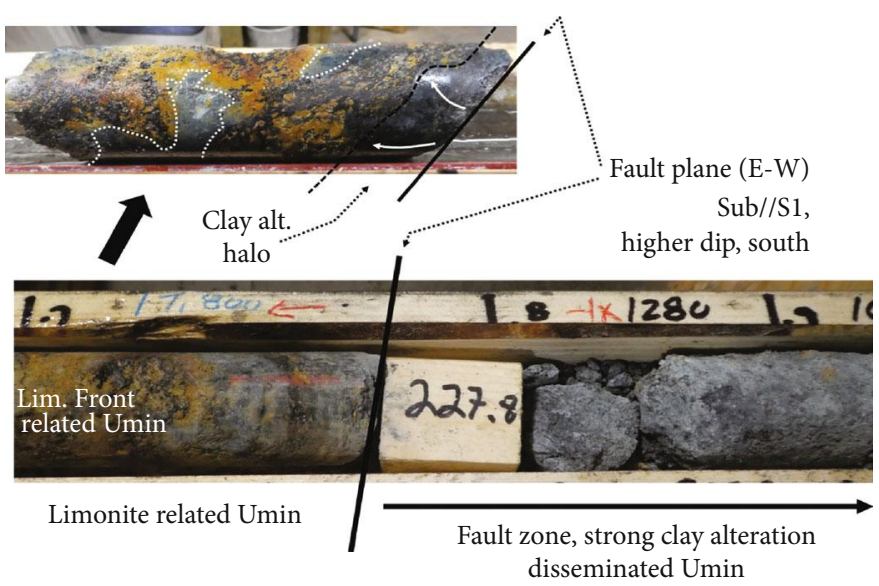

(g)

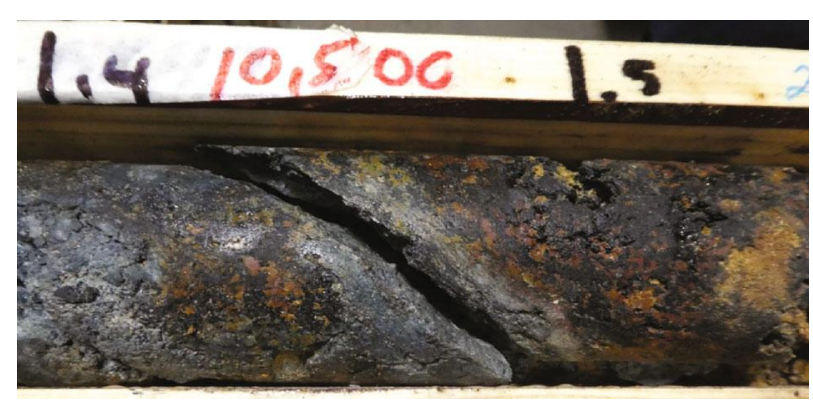

(h)

Figure 11: Drill hole ML-134. (a) General overview of the mineralized interval @205.3-249.2 m. (b) Microfractures filled with secondary graphite or dark chlorite @210.4 m, <830 cps. (c) Fracture and quartz-feldspar segregation-related mineralization @209.8 m, <15.340 cps. (d) Limonite oxidation front-related mineralization @217-217.3 m, $<21.630 \mathrm{cps}$. The sketch shows the geometric relationship between the front, the foliation, and the fold. (e) Oxidation front-related mineralization @221.4 to $221.8 \mathrm{~m},<11.700$ cps. The sketch shows the geometric relationship between the front and the foliation. (f) Upper contact of principal mineralization @223.5 m. (g) Lower faulted contact of principal mineralization @227.8 m. (h) Clay fault @227.4 m, 10.500 cps.

to rounded, $\mathrm{mm}$ to $\mathrm{cm}$ scale, clasts of pale green to grey chloritized pelitic gneiss cemented with green dark to black chlorite with disseminated mineralization. The edge of the clasts exhibits corrosion patterns (dissolution gulfs).

\subsubsection{Structural Interpretation and Controls on} Mineralization. The ductile patterns identified, noted as undifferentiated D1/S1 foliation (including shear zones, DBSZ and large folding), correspond to the main pre-Athabasca shortening event synchronous of the high temperature metamorphism with lit-par-lit melting of the paragneiss and anatectic sweats (regional D2/S2 event $[50,51]$ ). All previous deformation and foliation events are transposed to this event. D2/S2 is characterized by vertical open folds associated with a gentle shortening event. No well-developed foliation associated with D2/S2 is apparent.

The noteworthy change in the S1/shear zone pattern noted when moving from the periphery to the mineralized zone (from $\mathrm{W}$ to $\mathrm{E}$ ), from the same steeply dipping south sense of dip to a progressively conjugate north and south sense dip, with the plane poles progressively spanning from the north to the south in the stereoplots, is interpreted to reflect a conjugate shear pattern. This lateral evolution is visible on the drill sections as well (Figure 9(b)) and supports (i) the conjugate arrangement of S1/shear zones and (ii) the role of the antithetic shear bands favouring brittle reactivation and mineralization. The ATV oriented data from drill hole ML-137 supports the same structural interpretation of conjugate shears. This is presented in the synthetic cross section through the mineralized ore body in Figure 13(a). The 2D pattern of the shear zones in the barren western trend can be associated with noncoaxial deformation resulting in an asymmetric shear zone pattern with the same dominant dip to the south, while in the mineralized zone, the symmetric conjugated shear zone pattern indicates coaxial deformation ([52]) (Figures 9(d) and 13(b)).
Mineralization in Tri-Island is disseminated and fracture-related hosted within foliation and shears reactivated as breccia faults or veins. Most of the mineralized fractures are E-W, following the E-W orientation of the inherited, inferred conjugate, ductile fabric, and secondarily in NW-SE and NE-SW fractures. Although the uranium ore body is conformable with the inherited conjugate pattern, mineralization is inferred to be the result of post-Athabasca faulting reactivating the inherited ductile structures $[5,12]$. Post-Athabasca faulting in Martin Lake was recorded by the offset of the unconformity, the recurrent right-lateral strike-slip offset of the Tri-Island trend by globally N-Strending faults and the E-W faults that reactivated basement shears and propagated upwards into the sandstones. These types of faults resulted in minimal metric-scale unconformity offset but their role is inferred as critical in driving mineralizing fluids from the basement into the sandstones (i.e., Cigar Lake deposit, CL in Figure 1, [12, 53]). The cataclasticcorrosion wear breccia facies observed in drill hole ML-141, interpreted as mineralized fault breccias resulting from the combination of tectonic (oriented fracture network) and hydrothermal (chaotic breccia with "corrosive wear" texture) features. The increase of the number of faults when moving from the barren synthetic shear zone (west) into the mineralized conjugated shear zone (east) indicates favourable conditions to enhance brittle reactivation of conjugate shears allowing for the circulation of important amounts of fluid flow.

5.3. Structural Controls in the Spitfire Prospect: Hook Lake Project. The Spitfire uranium prospect is located at the southern boundary of the Hook Lake Project, along the Patterson Uranium District in the southwest Athabasca Basin (Figures 1 and 14). The Patterson Lake trend is a structural corridor (also called the Patterson Lake corridor) that hosts one of the world's largest high-grade uranium systems which 


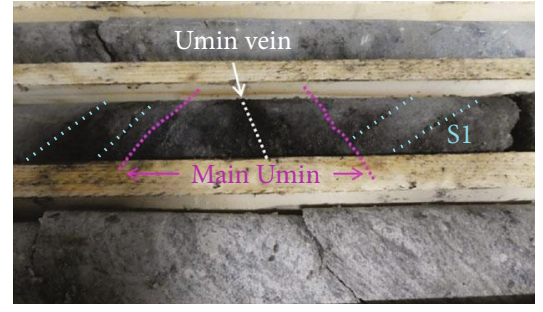

$<17.000$ cps

(a)

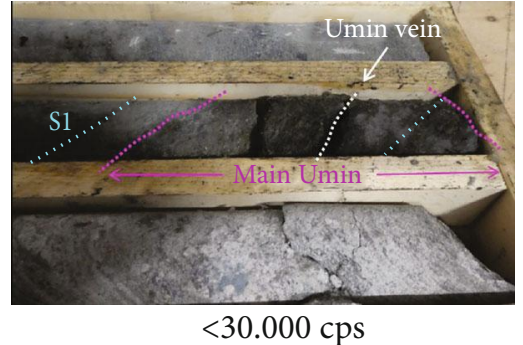

(b) $<12.000$ cps $<20.000 \mathrm{cps}$ $<30.000 \mathrm{cps}$

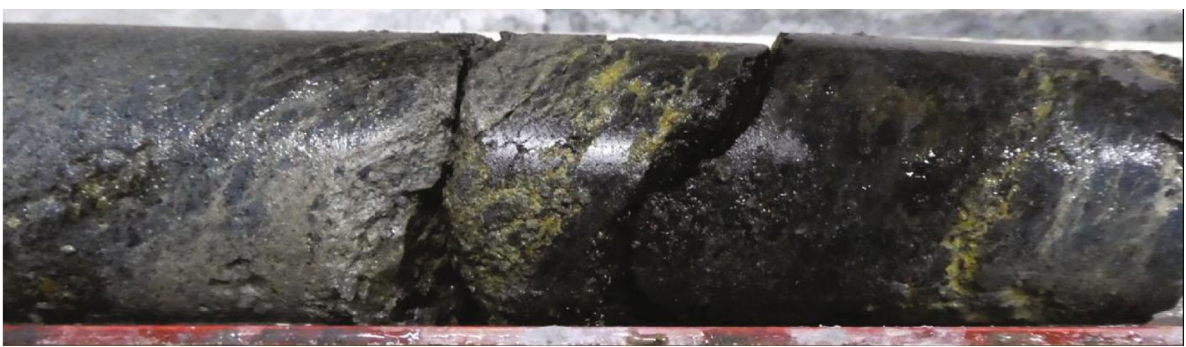

(c)
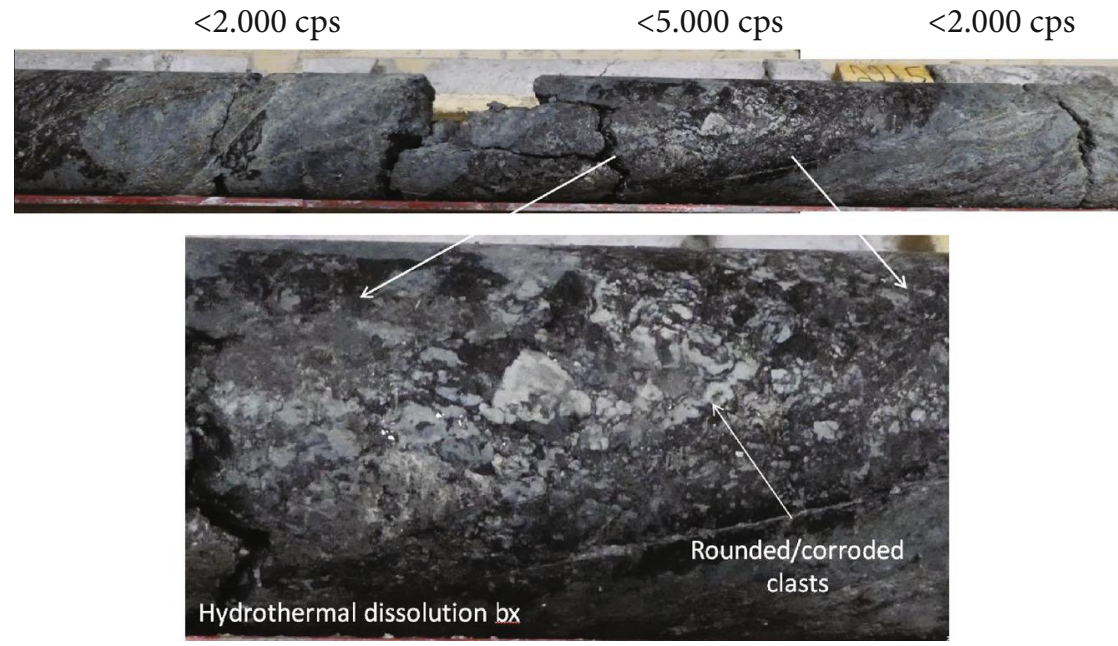

(d)

FIGURE 12: Drill hole ML-141. (a, b) Vein-related mineralization @216 m. (c) Vein-related mineralization @220 m. (d) Cataclastic-corrosion wear mineralized breccia @220 m.

includes Fission Uranium Corp.'s Triple R Deposit and NexGen Energy Ltd.'s Arrow deposit located several kilometers southwest of Spitfire (https:/purepoint.ca/projects/ hook-lake/). The Patterson Lake corridor is a crustalscale zone of heterogeneous high strain with a strike length of over $50 \mathrm{~km}$ and a width of 5 to $10 \mathrm{~km}$, hosted in Paleoproterozoic crystalline rocks of the Taltson Domain, which is part of the southwest Rae Province [22]. In the Hook Lake Project, three major basement lithologies are identified: orthogneiss derived from quartz monzodioritic and dioritic protoliths, a suite of mafic to ultramafic rocks that intruded the orthogneiss $[54,55]$, and pelitic gneiss or pseudoplites [33]. The Patterson Lake corridor also hosts ultrabasic intrusive rocks, carbonatite dykes, and voluminous hydrothermal-metasomatic rocks, accommodated deformation episodes in both the ductile and brittle regimes [22]. A subvertical fault system extending NE-SW at Arrow (Figure 1) has been interpreted as a chloritic-graphitic strike-slip dominated fault system of complex left-lateral Riedel-style geometry, where multiple brittle reactivations of primary shear fractures have occurred, allowing for migration of hydrothermal fluids, alteration of host rocks, and precipitation of uranium mineralization [20].

The high-grade Spitfire mineralization (Figure 14) was discovered in 2015. The mineralization is basement hosted below less than $150 \mathrm{~m}$ of Athabasca sandstone basin infill and expands southwest to join the Harpoon prospect (NexGen Energy Ltd.). The mineralization is hosted within a NE-trending, moderate to steeply SE-dipping graphite-rich shear zone (Figure 14) (https://purepoint.ca/projects/hooklake/). 


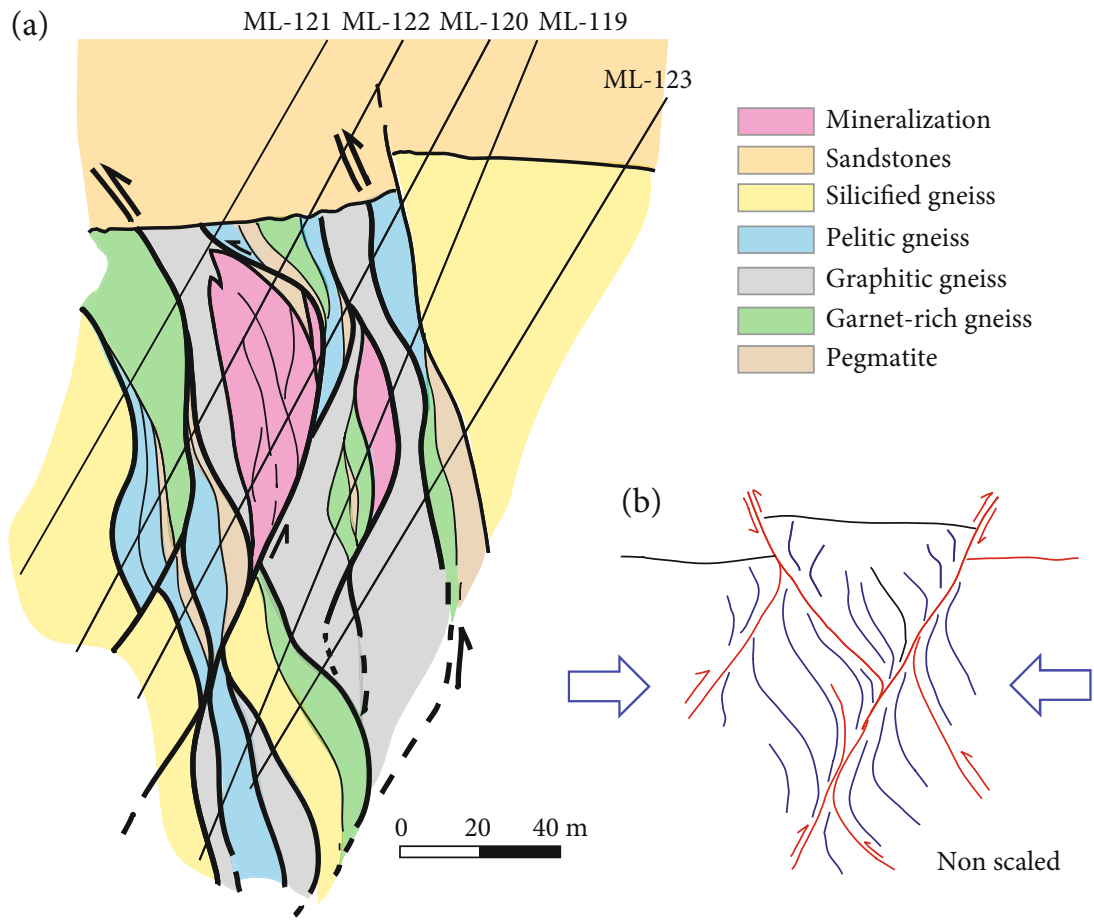

FIGURE 13: Cross section $b_{7}$ (Figure 9(b)) through holes ML-121 to ML-123 revisited taking into account the conjugated symmetric shear zone pattern attributed to coaxial deformation.

This section presents the 2016, 2017, and 2018 structural studies completed on the Spitfire prospect (Figure 14). It is based on observations on mineralized core, structural analysis of oriented fresh drill core (holes HK16-34, HK16-37, HK16-39, HK16-43, HK16-47, HK17-43, KH17-56, HK1760, HK17-61, HK17-62, HK17-79, HK17-80, and HK1882 ), and of ATV data. The ATV was run and processed by DGI Geoscience Inc., and interpreted by the authors. Additional observations of the mineralized intervals were performed in the revisited holes HK14-9, KH14-17, HK15-25, and HK15-21.

\subsubsection{Hosting Rocks and General Geometry of the Composite} Ore Body. Observations of fresh rocks from drill holes allowed identifying the following lithologic sequence, from top to bottom: (1) orthogneiss with granitic composition (i.e., granodiorite), with preserved feldspars phenocrysts and with different degrees of hydrothermal quartz silicification. These are partially hematized below the unconformity due to pre-Athabasca basin paleoweathering and strongly silicified at the contact with the underlying graphite-rich mylonite zone (see below). (2) Mafic rocks that intrude through the contact between the felsic orthogneiss and the underlying graphitic gneiss (mylonite zone). This intrusive is pale green, strongly chloritized and argillized. (3) Mylonite or shear zone ( $>50 \mathrm{~m}$ thick) which contains (3.1) garnet-rich granitic gneiss. Fresh garnets out of the mylonite zone evolve to chlorite-rimed at the edges and completely chloritized within the mylonite core. The garnets are progressively stretched and rotated indicating a stage of high temperature deformation $\left(>600-800^{\circ} \mathrm{C}\right)$; (3.2) very fine-grained mafic rocks with local millimeter-scale but very abundant garnets.
These mafic rocks vary in location from above to below the graphitic pelite. Fresh examples of these mafic rocks contain disseminated sulfides; (3.3) graphitic-rich pelitic gneiss, pyrite-rich at the top, within the mylonite core (ultramylonite). (4) Pyroxene-garnet-rich mafic rocks with pyrite as disseminated grains or in veinlets, and magnetite in veinlets. Hydrothermal quartz is abundant locally modifying the pelitic gneiss fabric and imparting a gneissic fabric. Preliminary geochemical and multielement analysis currently in progress show patterns suggesting that the granitoids and associated rocks belong to four disctinct groups: TTG (tonalite, trondhjemite, and granodiorite), sanukitoids, BADR (basalt, andesite, dacite, and rhyolite), and boninites. The entire package of rocks is affected by different degrees of silicification, chloritization, and clay alteration. However, the presence of silicified granitic gneiss and the occurrence of chlorite-altered, mafic intrusives at the interface between the graphitic gneiss (mylonite zone) and the overlying granodiorite is a characteristic of the Spitfire prospect. Most of the mineralization is hosted following this mechanical discontinuity [33]. Below the graphitic mylonite zone, the rocks are relatively fresh.

The ore body, depicted within a $500 \mathrm{ppm}$ cut-off envelope, strikes NE, is approximately $350 \mathrm{~m}$ in strike-length with a thickness up to $30 \mathrm{~m}$ (Figure 14). In the NE, the ore body extends down at least $120 \mathrm{~m}$, from $320 \mathrm{~m}$ to $225 \mathrm{mASL}$ (Figure 14). Figure 15 displays a 3D cartoon of the southwestern half of the ore body (Figure 15(a)). For simplicity, we term the horizontal parts of the ore body "wings" and the vertical extension "root". Figure 15 also shows the location of the representative mineralized samples and main structural observations from the root and the wing (Figures 15(b)$15(f))$. The root contains the high-grade mineralization in 


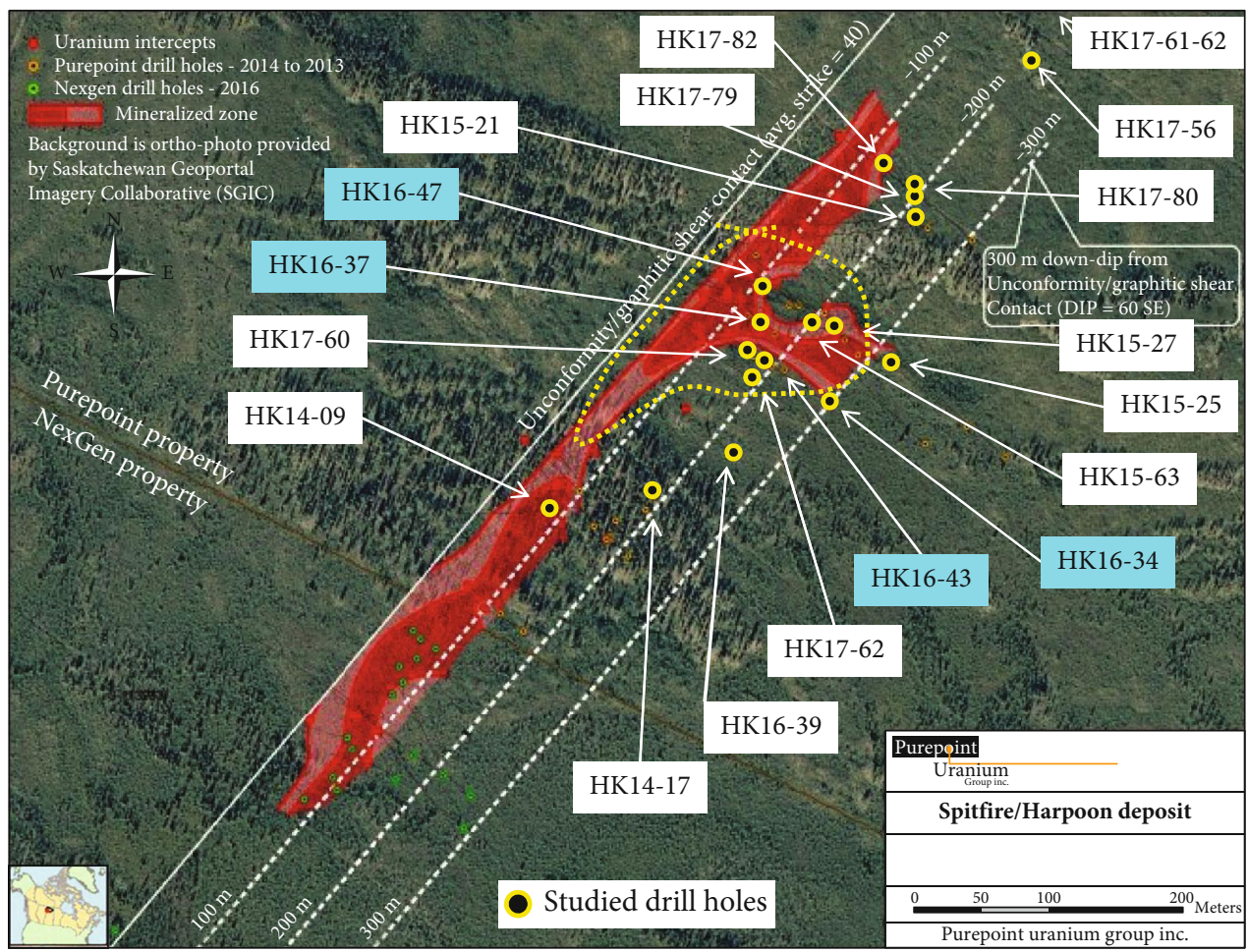

FIGURE 14: Ore body footprint and collar location of the studied inclined drill holes (map from Purepoint Uranium Group, 2016. Drill holes provided with ATV are framed in blue. Yellow dotted line circles the area represented in the 3D sketch of Figure 15. Modified from Purepoint's web page (https://purepoint.ca/projects/hook-lake/).

its deeper part, associated with pyrite-filled veins (Figure 15(f)) and breccias with corrosion wear textures. Breccia clasts are remnants of the pale-green mafic intrusive. The pseudobreccia cement is formed by grey microcrystalline chlorite that fills spaces left by dissolution and hosts the mineralization which coats grain surfaces, fills intragrain porosity, forms microveins in quartz, and replaces micropyrites and parts of large pyrite grains [33]. Mineralized veins are observed at the upper part of the root and occur parallel-to-oblique to S1 (Figures 15(d) and 15(e)). Proximal to the root zones, the wings are characterized by mineralization filling veins parallel to $S 1$ or as disseminations in reduced zones in both the graphitic gneiss and the overlying mafic rocks (Figure 15(c)). The distal zones of the wings are characterized by foliationcontrolled disseminated mineralization (Figure 15(b)) and secondary, remobilized mineralization at redox fronts associated with limonite. Hematite and limonite oxidation are characteristics of the wings and generally of the upper part of the ore body. Hematization disappears at depth, with no oxidation present along the root at depth. Corrosion wear textures are also observed locally in the wings.

5.3.2. Structural Analysis and Mineralization Settings. Five drill holes had both good core recovery and acoustic televiewer data collected. The study of four of them is presented hereafter (see location in Figure 14).

Drill hole HK16-34 did not intersect any mineralization; rocks are quite fresh and show little deformation. This hole makes part of the nonmineralized holes that were studied as reference for the comparison of shear/fault zone arrangement between nonmineralized and mineralized holes. Foliation (S1) homogeneously trends NE and steeply dips SE, with rare local changes in dip or azimuth to NNE or WNW. The graphitic gneiss unit (357.4 to $378 \mathrm{~m})$ shows high strain, but only the top contact above the pyrite bearing graphitic gneiss appears as an unambiguous major shear zone transposed to the general S1. Local and discrete ductile shears and cataclastic shears were interpreted as NE-trending reverse shears. Local minor to medium scale fractures and faults crosscut foliation. Most of the time, faults are recognizable by the presence of centimeter-scale clay gouges. Their orientations and types are (i) E-W-trending faults often displaying right-lateral reverse strike-slip kinematic indicators, (ii) NW-SE-trending fracture or fault corridors, and (iii) rare N-S- and NE-SW-trending single fractures or faults.

Drill hole HK16-47 intersected three mineralized intervals (Figure 16). (i) The upper mineralization is patchy, occurring over an approximately $7 \mathrm{~m}$ thick interval. It contains relatively low grades (ex. $0.06 \% \mathrm{eU}_{3} \mathrm{O}_{8}$ over 1.7 meters, from gamma probe (gp)) and exhibits fracture/vein-related oblique and parallel to foliation mineralization from 178 to $185 \mathrm{~m}$ (Figure 16(a)). Mineralization is hosted within granitic gneiss. Both mineralized foliation and fractures are very similar in orientation occurring between N020 and N040, and dipping most often from low $\left(40^{\circ}\right)$ to moderate $\left(70^{\circ}\right)$ to the east (Figure 16(a)). (ii) The intermediate mineralization is approximately $15 \mathrm{~m}$ thick, relatively low- to medium-grade (ex. 10.3 meters of $0.18 \% \mathrm{eU}_{3} \mathrm{O}_{8}$, gp) within a ductile shear zone at the contact between the pelitic graphitic gneiss and 
(b)

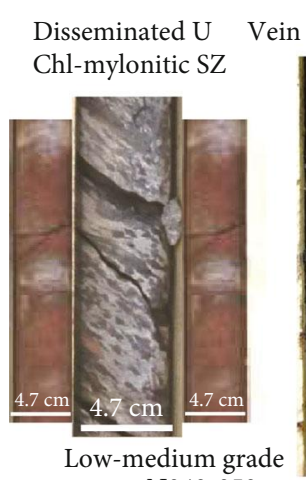

(c)

in related U //S1 (d)

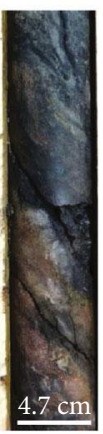

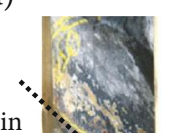

(e)

Disseminated to

massive U //S1

in SZ \& redox fronts

(a)

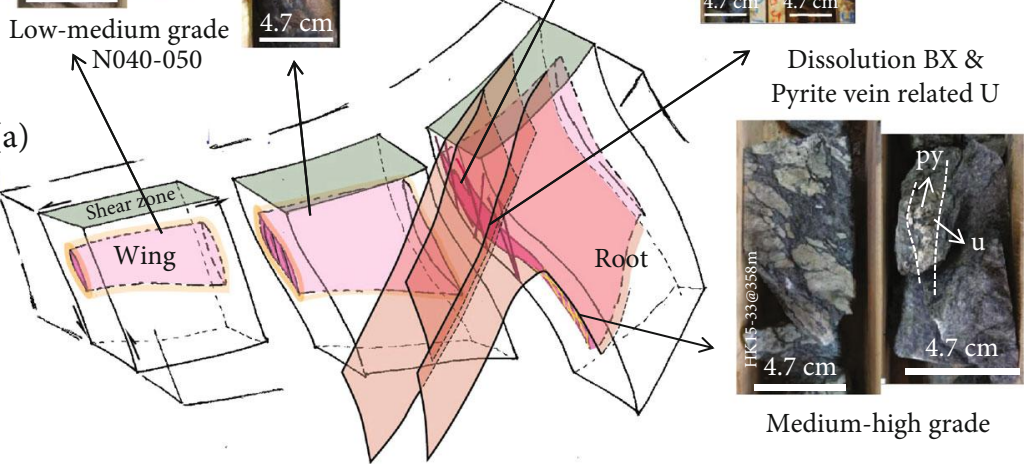

FIGURE 15: Synthetic 3D sketch of the Spitfire with a representative sample of mineralized drill core. Chl: chlorite; SZ: shear zone; U//S1: uranium vein parallel to foliation; BX: breccia; Py: pyrite; U: uranium.

the granodioritic/silicified gneiss (Figure 16(b)). Mineralization is dominantly parallel to S1 with fracture-related mineralization also visible subparallel and gently crosscutting the foliation. Both mineralized shears/foliation and mineralized fractures strike within N015 and N025 (Figure 16(b)). (iii) The lower mineralization is the main ore zone in this hole with $20.1 \mathrm{~m}$ of $0.88 \% \mathrm{eU}_{3} \mathrm{O}_{8}$, gp (Figure $16(\mathrm{c})$ ). This lower ore body is divided into two parts: (a) the upper part, 216$226 \mathrm{~m}$, contains the highest grade mineralization in this hole which is oxidized massive and botryoidal mineralization parallel to S1; (b) the lower part is formed by disseminated low-grade mineralization in a grey chlorite-clay sheared and altered zone. The shear zone is structurally characterized by two sets of mineralized shears striking N020 and N110 (Figure 16(c)). Nonmineralized faults in drill hole HK16-47 group in two main sets E-W (generally moving from WNW-ESE and WSW-ENE, Figure 16(a)) and NW-SE (Figure 16(b)). These faults clearly offset mineralized settings and locally juxtapose different lithological units. They are often highlighted by clay-gouges or clay breccias.

Drill hole HK16-43 shows a low- to medium-grade mineralization interval between 215 and $263 \mathrm{~m}$ (7.4 meters of $0.24 \% \mathrm{eU}_{3} \mathrm{O}_{8}$, gp, Figure 17), hosted in a shear zone involving granitic and graphitic gneiss, respectively. The main orientation of this shear zone is NNE (N010-030), with (a) dominant mineralization foliation and shears parallel, massive, or botryoidal and (b) fault/vein-related mineralization common through the mineralized interval (Figures 18(a) and $18(b))$. The mineralization is disseminated in cataclastic gouges or is massive as vein cement (Figures 18(c) and $18(d))$. Vein-related mineralization is often visible leaking from the vein into the foliation within fracture damage zones
(Figure 18(b)). Mineralized fractures are subparallel to the shear zone. The NNE orientation of both foliation and mineralized shears and veins is a remarkable feature that contrasts with the NE (N040-N050) orientation of foliation patterns along the nonmineralized interval above $215 \mathrm{~m}$ (Figure 17). Nonmineralized fractures and faults arrange in three main sets: (i) a dominant WNW-ESE-trending set, dipping in a wide range from low angle $\left(20^{\circ}\right)$ to steeply dipping $\left(70^{\circ}\right)$. The reason for this wide range in dips may be related to several episodes of reactivation; (ii) a NE-SW set. This set crosscuts foliation with a very narrow angle; dips are generally steep $\left(70^{\circ}\right)$; and (iii) an E-W- (or ENE-WSW-) trending set of low to moderate dip to the south. All these fault sets offset shear zones and mineralized settings.

Drill hole HK16-37 intersected one mineralized interval consisting of relatively high-grade mineralization from 269.6 to $275.0 \mathrm{~m}$ (5.4 meters of $1.21 \% \mathrm{eU}_{3} \mathrm{O}_{8}$ ) (Figure $18(\mathrm{e})$ ). The high-grade mineralization is hosted within a N045-striking shear zone and is formed by dominant massive and/or disseminated pitchblende with pyrite along foliation, disseminated mineralization within a chlorite/pyrite cement of a quartz breccia showing corrosion wear textures, and two $\mathrm{mm}$ thin veins infilled by relicts of white quartz and black material (probably pitchblende and dark chlorite). These latter veins strike N015-020, dip between 50 and $60^{\circ}$ to the SE, and branch into the chlorite/pyrite shear zone and quartz breccia.

Table 1 presents the synthesis of the most common and frequent structures observed both on core and from ATV data.

5.3.3. Structural Interpretation and Controls on Mineralization. The comparison of the oriented data from 


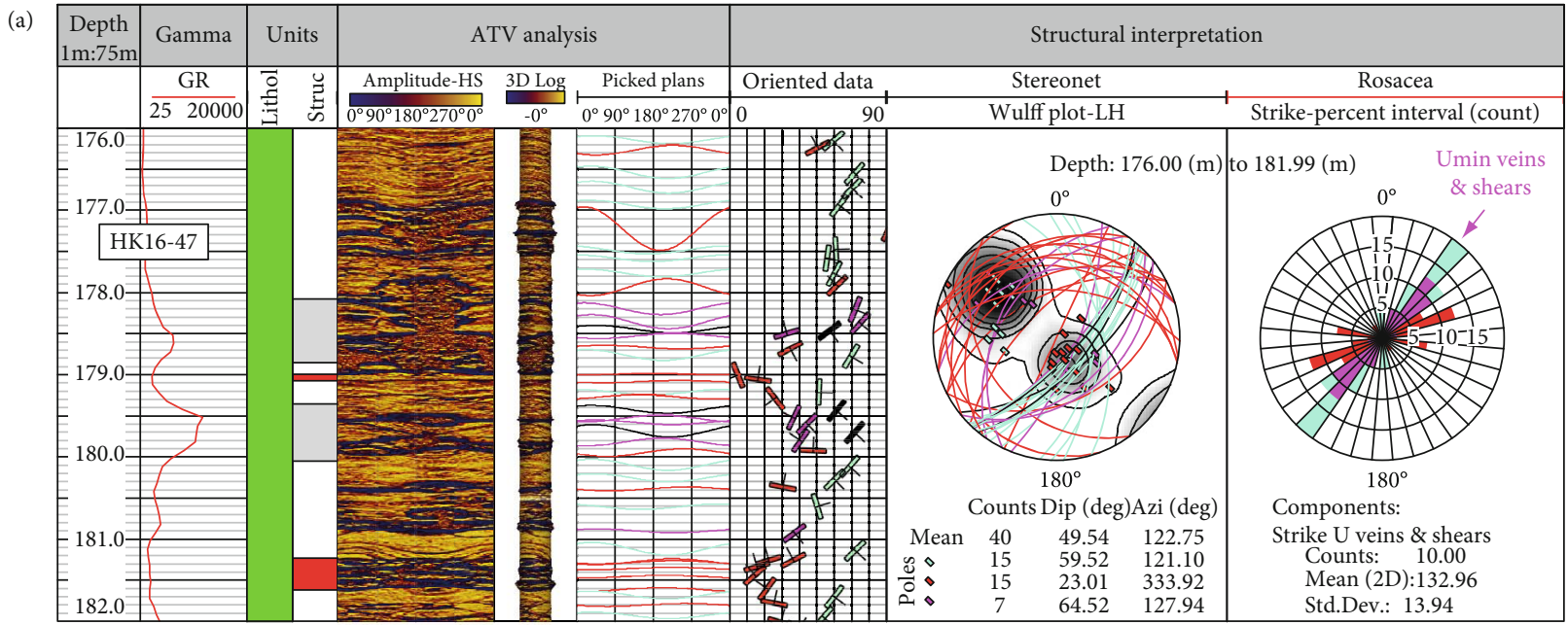

(b)

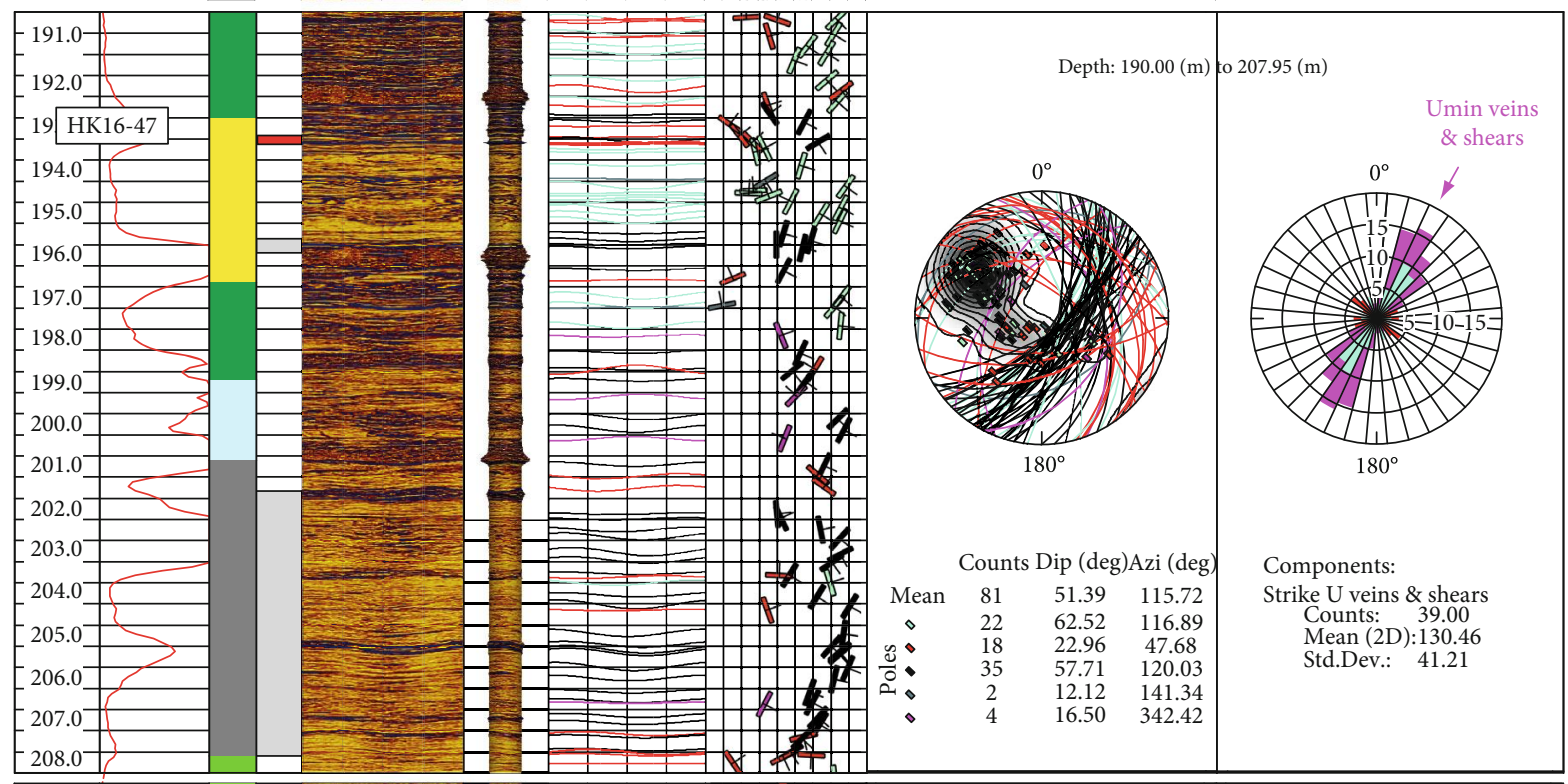

(c)
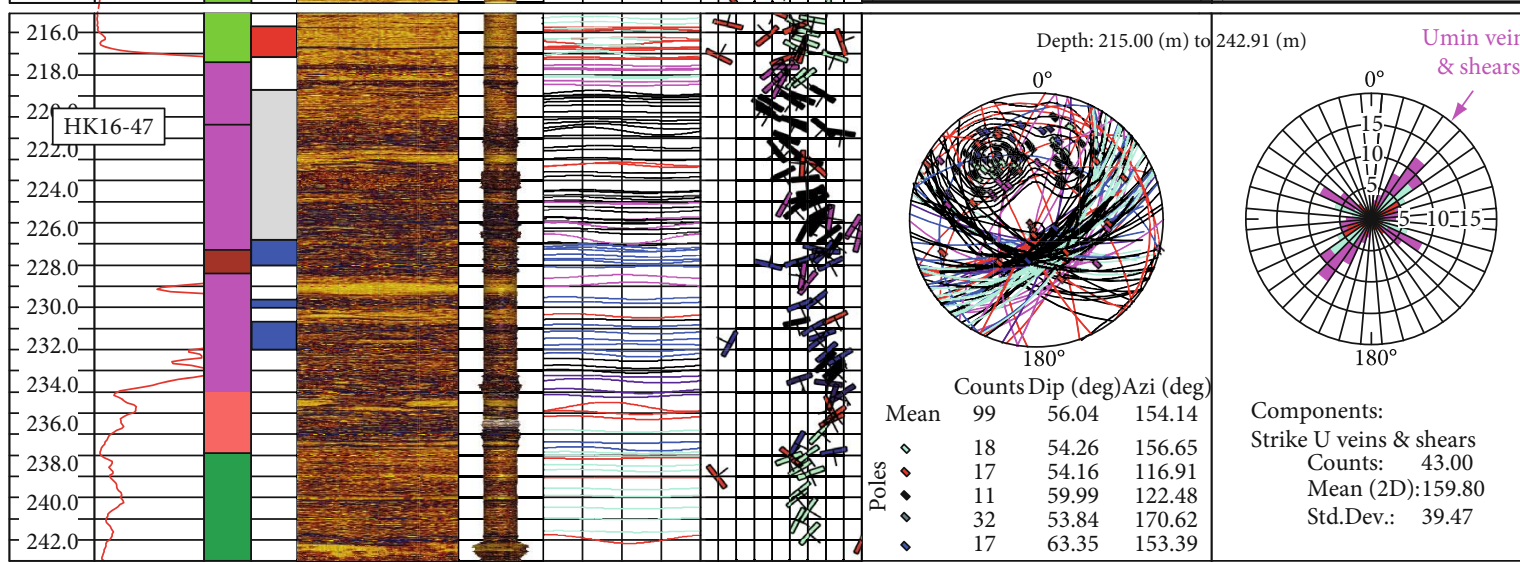

Components:

Strike $\mathrm{U}$ veins \& shears

Counts: $\quad 43.00$

Mean (2D):159.80

Std.Dev.: 39.47

FIGURE 16: ATV data structural analysis from drill hole HK16-47. Zoom in on oriented data of (a) the upper mineralized zone 1, (b) the intermediate mineralized zone, and (c) the lower mineralized zone. Mineralized shears are in this figure in black. Umin: uranium mineralization. Legend in Figure 2.

ATV between nonmineralized (i.e., drill holes HK16-34 and HK17-70) and mineralized intervals (i.e., drill holes HK1647,43 and 37) reveals a noteworthy change in both (i) the strike of the S1/shear zone pattern from NE-SW $(\approx$ N040-
050) to NNE-SSW ( $\approx$ N010-030) (Figures 19(a) and 19(b)) and (ii) the dip from steeply dipping higher than $70^{\circ}$ to the SE of the nonmineralized intervals to a shallower dip ranging less than $65^{\circ}$ to the $\mathrm{SE}$ of the mineralized intervals 


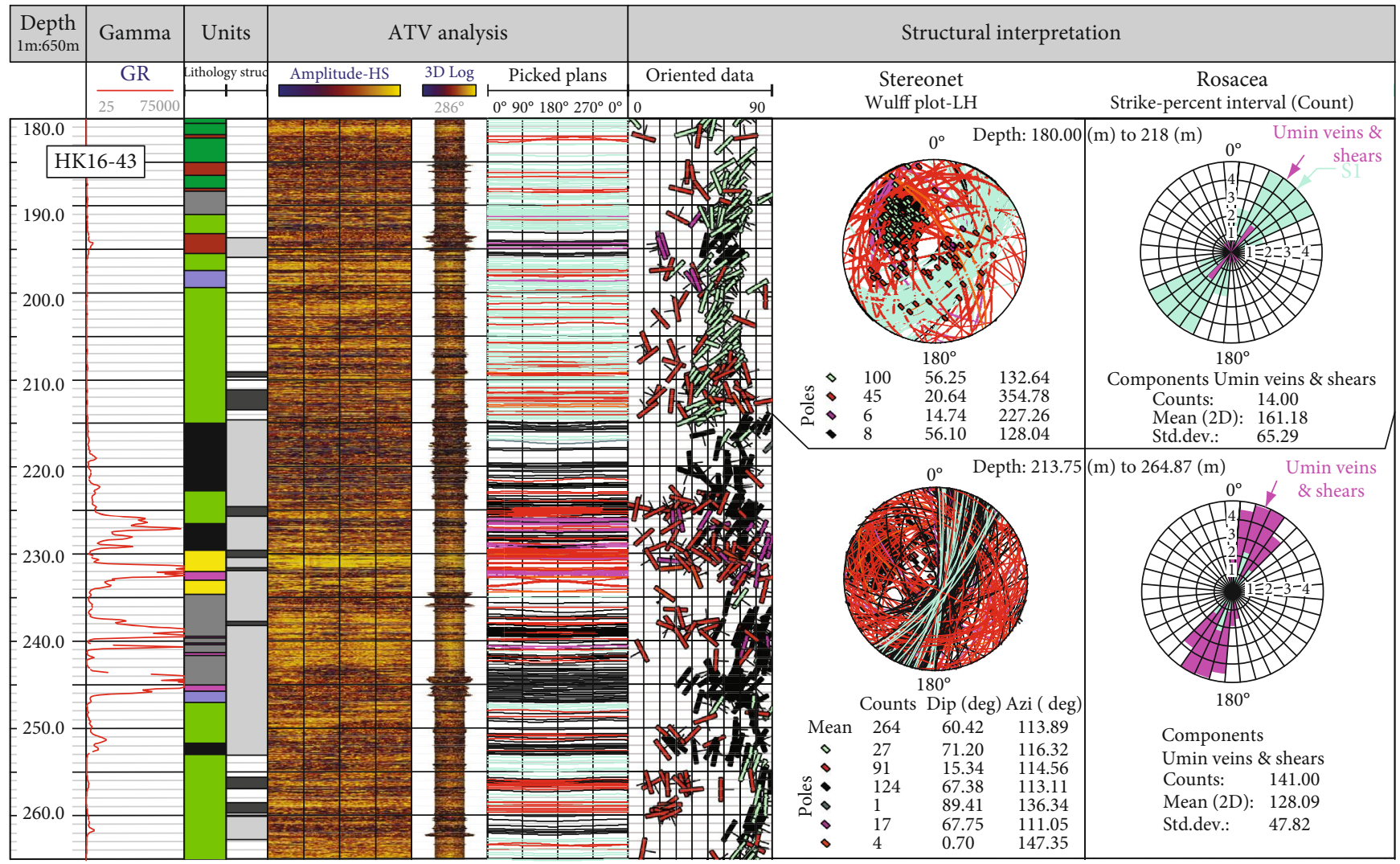

Figure 17: ATV data structural analysis from drill HK16-43 ATC and structural interpretation. Note the rotation of the nonmineralized (blue, upper interval) to the mineralized (black, lower interval) shears from NE to NNE. Umin: uranium mineralization.

(Figure 19(c)). This change in both strike and dip is interpreted as related to local bends, both laterally and vertically, along the trace of the graphitic shear zone favourable for the formation of dilational jog zones during inferred late reactivation of the graphitic shear zone where mineralization was trapped (Figure 19(d)). Few kinematic indicators could be collected from drill core; however, those that were obtained support this interpretation. Slickensides are commonly observed along graphitic planes and in some secondary faults (Figure $7(\mathrm{~d})$ ). Unfortunately, most are ambiguous without a clear sense of displacement or indicating various episodes of reactivation. Few good slickensides could be observed on N-S/NNE-striking faults parallel to the main foliation within shear zone recording unambiguous leftlateral reverse strike-slip kinematics (i.e., in drill hole HK17-72, Figures 7(d) and 19(d)). These data attest for at least one episode of N-S shortening. An episode of N-S compression could explain the opening as 3D dilational jogs along NE to NNE bends along the major shear zone favouring the development of N-S/NNE-striking mineralized veins. Although this is our preferred interpretation it does not negate the hypothesis that mineralization developed at the intersection between a NNE-trending fault with the NEtrending graphitic shear zone (Figure 15(a)). This alternative hypothesis would imply a very different kinematic context than that suggested herein.

\section{Structural Controls and Mechanisms of Fluid-Rock Interaction}

The structural analysis of the Sue and Spitfire sites highlights the same type of geometrical trap in the form of fault bends inducing the formation of dilational jog structures to which the main mineralization is correlated. Fault bends have 3D geometries and occur when the NE-trending major shear/fault zone changes orientation from NE to NNE and dips shallow from $70^{\circ}$ to $40^{\circ}$. In such a fault bends, dilational jog zones opened when brittle left-lateral reverse strike-slip reactivation occurred. In such a configuration, foliation was opened as a "mille-feuille cake", veins opened parallel or oblique to foliation (mode I or crack veins NNE-striking), and local cataclasites formed. In such a structural and geometrical trap (jogs), mineralization occurred disseminated along foliation planes (Figures 20(a) and 20(b)), sealing veins (Figure 20(c)), sometimes sealing local cataclasites (Figures 12(d) and 20(d)), and penetrating into the host rock from both foliation planes and veins (Figure 20(e)). One of the common and spectacular textures observed in all studied sites associated with or surrounding uranium mineralization is the cataclastic-corrosion wear breccia facies described above (Figures 12(d) and 20(d)). This breccia formed by chaotic, subangular to rounded, heterometric clasts with in some cases the disseminated or botryoidal mineralization within 


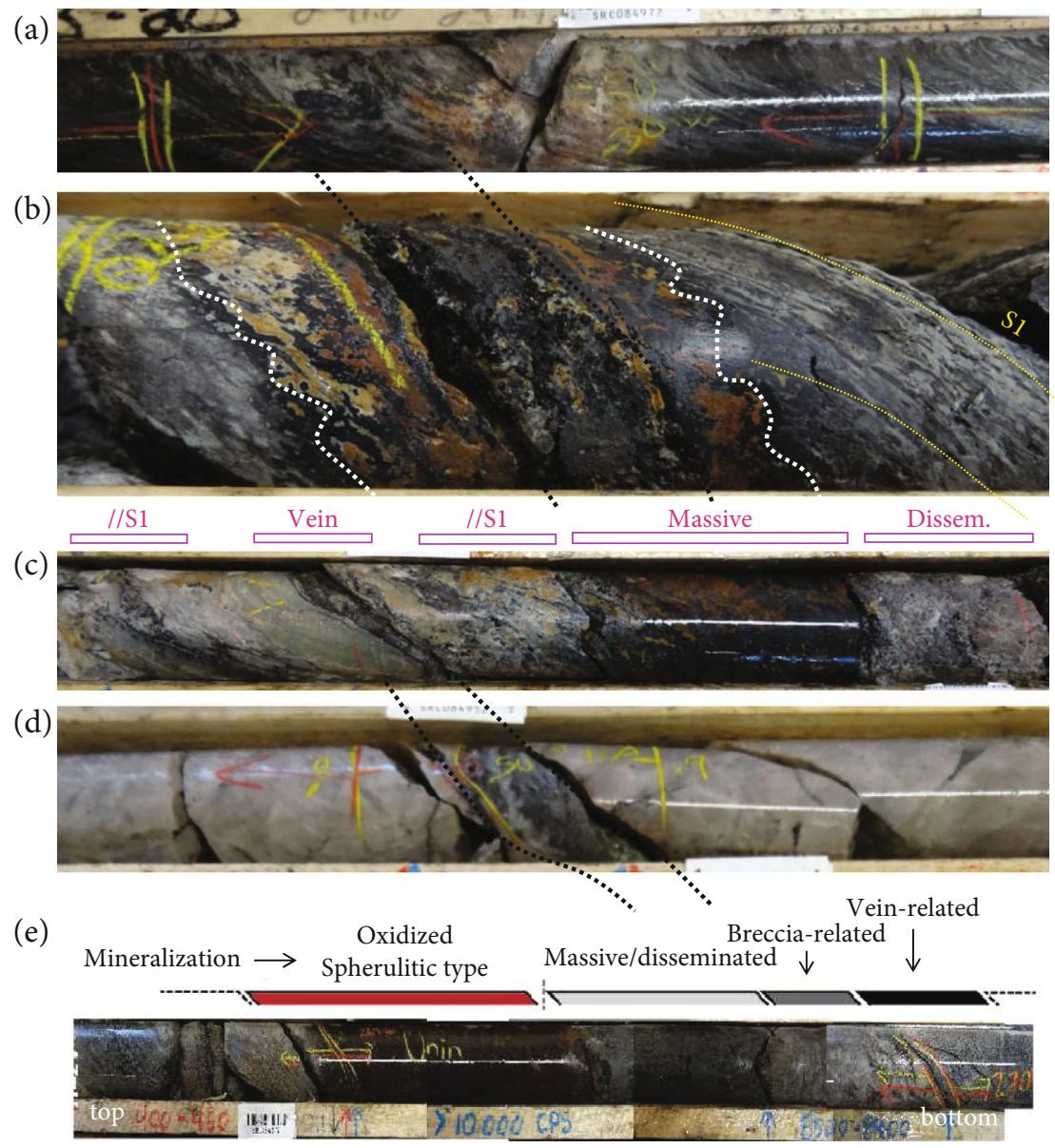

FIgURE 18: Uranium mineralization in drill hole HK16-43: (a) parallel to foliation mineralization, (b) vein-related mineralization crosscutting foliation, (c) disseminated in cataclastic gouges to massive as vein cement, (d) mineralized vein through a quartz vein, and (e) high-grade mineralized interval in drill hole HK16-37.

the chloritized matrix, exhibits pitting or subsurface attack of the edges of clasts (dissolution gulfs) indicating strong corrosion or dissolution. Detailed observation of less developed cataclastic-corrosion breccias (protobreccias) still allows for the observation of the initial microfractures through which fluids flowed (Figures 20(e) and 20(f)) and from by which dissolution fluids leaked and pervasively invaded the host rock (Figure 20(g)). In well-developed breccias, initial microfractures are completely obliterated suggesting that the chemical mechanism of dissolution takes over the mechanical mechanism of fracturing. Disseminated and parallel to foliation mineralized veins are more abundant in pelitic gneisses. In these cases, vein walls appear as planar with patterns of dissolution slightly visible with the naked eye but visible on thin sections (Figures 20(b) and 20(c)). Fracture-related corrosion wear textures or cataclasticcorrosion breccias are much better developed in (granular) orthogneisses because microfractures often reuse intergrain boundaries (Figure 20(e)). Corrosion/dissolution patterns attest for high amounts of hydrothermal fluid flow and enhanced fluid-rock interaction in dilational jog zones. When the dissolution mechanism takes over the fracture mechanisms, fluids can move far from jog zones and form ore bodies bigger than the size of jogs structural traps, hiding the original link to the structural trap. Cataclasticcorrosion breccias or similar dissolution patterns have been observed in other deposits as for example in Sue [45], Shea Creek [56], Midwest (Figure 20(h)), or Caribou (McClean Project), often described as "wormy" facies (Figure 20(f)) (i.e., [57]).

The structural analysis of the Tri-Island showing reveals that mineralization occurs at the same location of a noteworthy change in the S1/shear zone pattern from west to east along with a change in dip from a steeply dipping south sense of dip to a progressively conjugate north and south sense of dip (synthetic to the south and antithetic to the north). This lateral evolution supports two ideas: (a) the conjugate arrangement of S1/shear zones and (b) the role of the inherited antithetic shear bands favouring brittle reactivation and mineralization in the basement revealed by the increasing number of faults when moving from the barren synthetic shear zone (west) into the mineralized conjugated shear zone (east). A similar conjugated shear arrangement has been recently observed by Orano's geologists within the basement of the giant Cigar Lake deposit (Figure 1) and is used to explain the bump at the unconformity associated with the deposit, as well as the conjugated deformation bands observed within the overlying sandstones (O. Gerbeaud, 


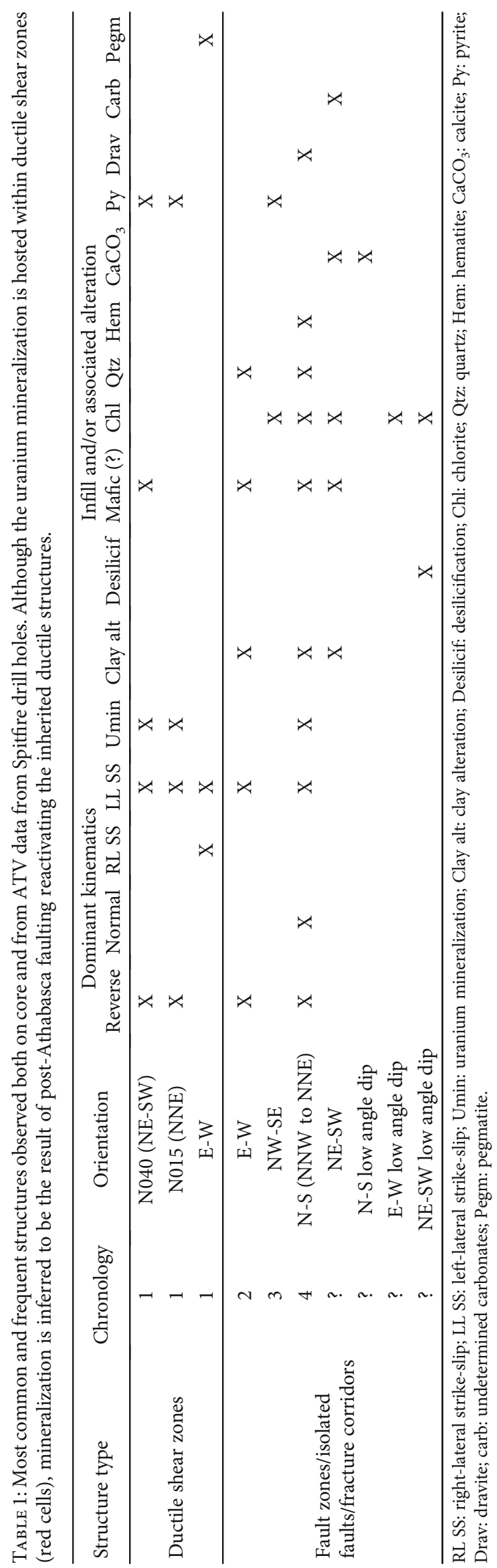




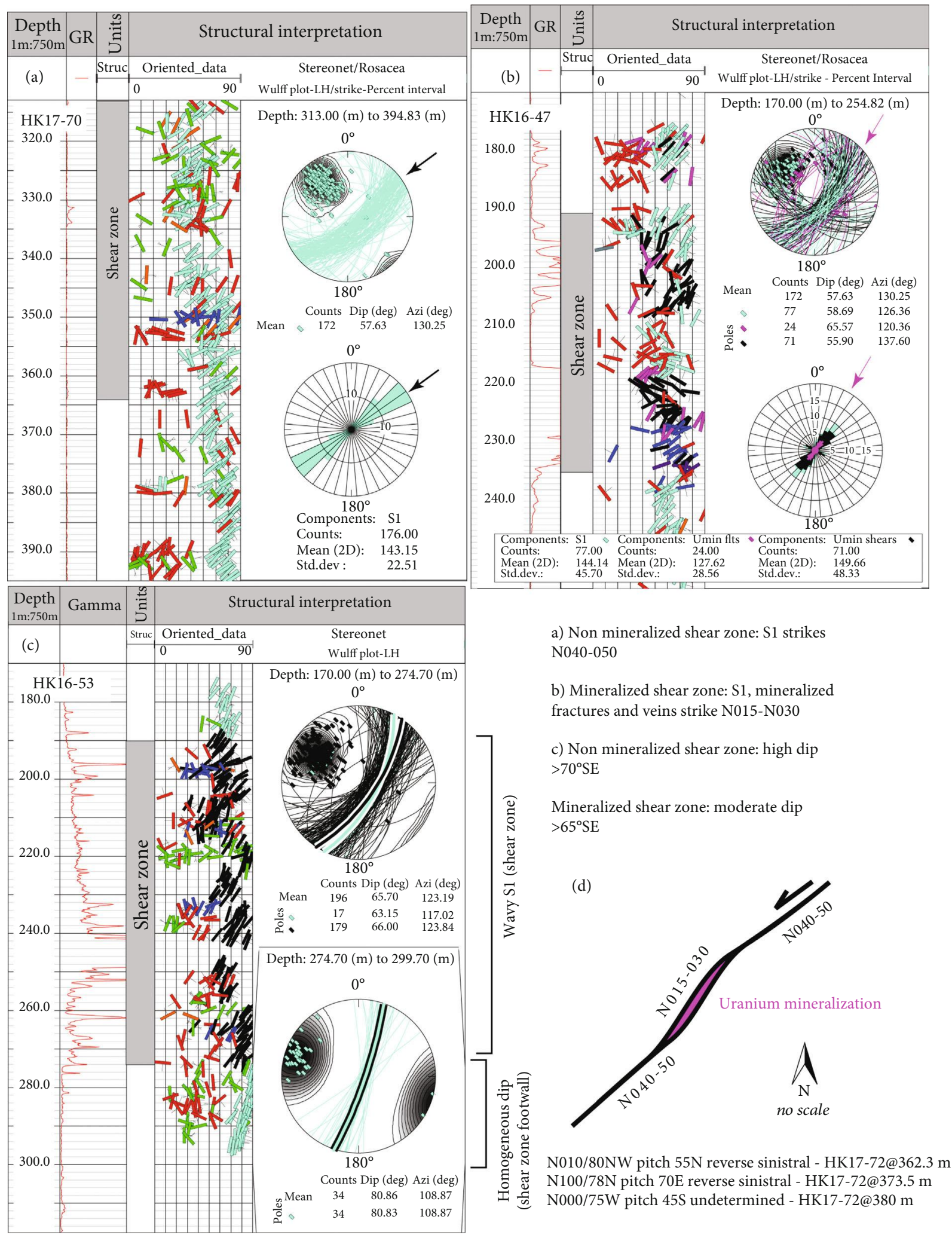

FIGURE 19: Comparison of the oriented data from ATV between nonmineralized and mineralized drill hole intervals in Spitfire. (a) Oriented data from the nonmineralized drill hole HK17-70. (b) Oriented data from the mineralized drill hole HK16-47. Note the change in orientation of the shear zone indicted by the arrows. (c) Oriented data from mineralized drill hole HK16-53. Note the change of the dip from the shear zone to the footwall. (d) Sketch showing the structural interpretation as a dilational jog opening within which the mineralization is trapped. Oriented data from drill hole HK17-72 is given. 

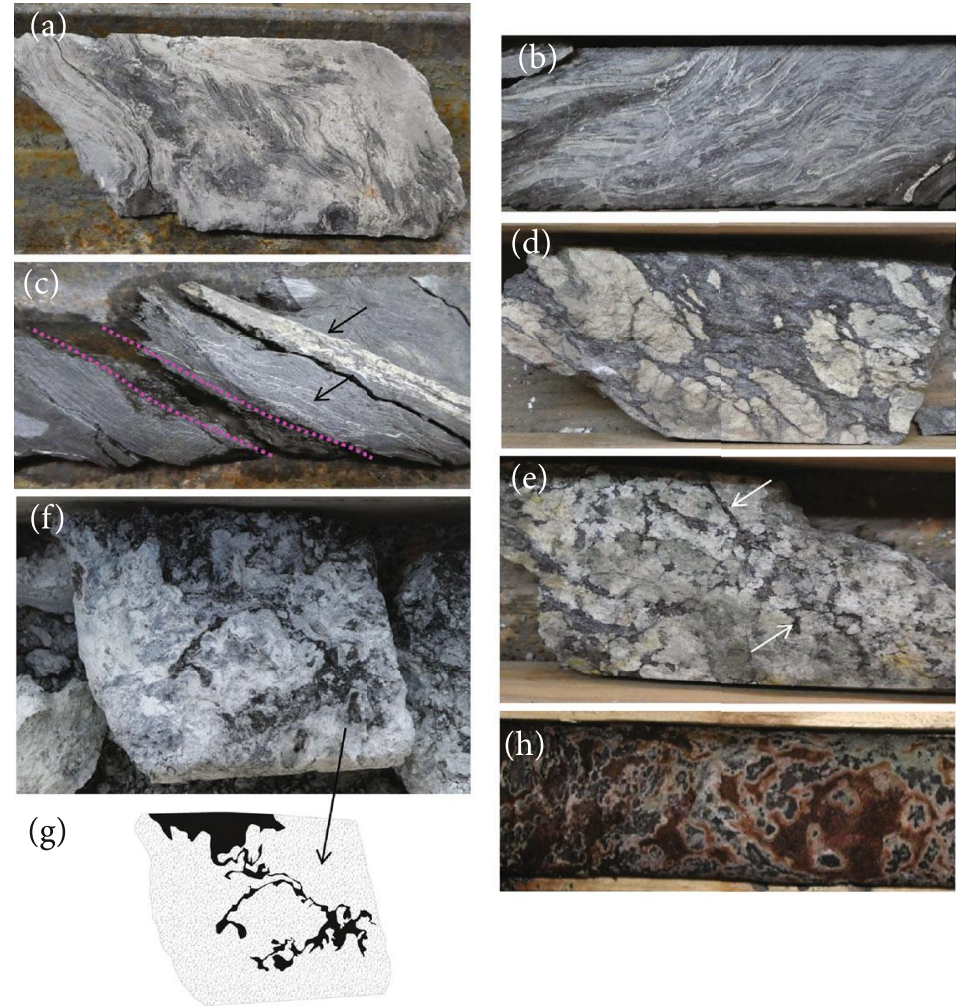

Figure 20: Deformation patterns and textures observed in mineralized dilation jog zones. (a, b) Reopened foliation with disseminated mineralization in a graphite-rich shear zone (HK18-82@263.9 m, 3800 cps; HK17-80@261.2 m, 5500 cps, respectively). Reopened foliation is underlined by pale grey clay (a) and white clay-carbonate (b) sealed veins. (c) Mineralized vein (pink) with parallel white clay-carbonate and quartz veins (arrows) reopening foliation (HK17-79@278.3 m, >10.000 cps). (d) Well-developed cataclastic corrosion/dissolution breccia (HK15-33@358 m). (e) Protocataclastic-corrosion/dissolution breccia still showing the initial microfractures from which fluids leaked into the host rock (HK15-33@357 m). (f) Protocataclastic corrosion/dissolution breccia from Midwest deposit (MW-855A, $500 \mathrm{cps}$ ). (g) Sketch of (f) showing the corrosion/dissolution pattern. (h) «Wormy » texture with mineralization from McClean Project (Caribou). Precise location unavailable (see [57]). Scale: diameter of the drill core of all pictures is $8.5 \mathrm{~cm}$.

Orano's geologist, pers. comm.). Cataclastic-corrosion breccias are also observed in such type of conjugated structures (Figure 12(d)).

The structural analysis of the Sue and Spitfire sites and observations on drill core also indicate that the reactivation or reuse of the inherited ductile fabric for fluid flow and trapping was enhanced along strong lithology contrasts. At the Sue deposits, the correlation between drill holes indicates that mineralization follows the regional NNE graphitic shear zone which constitutes the main mechanical discontinuity between the Collins Bay orthogneiss dome in the east and the silicified metasedimentary rocks in the west. This contrast in competency likely served as a conduit which enhanced fluid flow and fluid-rock interaction. Abdelrazek et al. [33] show that in Spitfire, most of the mineralization is hosted following the mechanical discontinuities between the silicified felsic gneiss and the chlorite altered mafic rocks at the interface between the graphite-rich gneiss (shear zone) and the overlying granodiorite. Abdelrazek et al. [33] suggest that the permeability through the shear zones was first enhanced by mineralogical changes during metamorphicretromorphic evolution and hydrothermal alteration that modified the rheology of the graphite-rich gneiss increasing the competence contrast with the surrounding lithologies and favouring brittle reactivation by combination of physicochemical mechanisms (brecciation and dissolution/corrosion) in shear zone bends (jogs) and conjugate shear zones as determined in this work.

\section{Implications on the Tectonic Regime}

The two different arrangements of mineralization traps described above, dilational jogs and conjugate shears, may respond to the two major orientations of shear zones that have been classically observed within the basement by systematic structural measurement and correlated at the regional scale by derived structural maps from the magnetic field: main N- to NE-SW- and E-W-trending [5, 50]. Jeanneret et al. [50] attribute the formation of the E-Wtrending shears to the earlier $D_{1} / S_{1}$ ductile deformation episode of N-S compression [50]. These authors attribute the $\mathrm{D}_{2} / \mathrm{S}_{2}$ ductile event to the formation of the NE-trending major shear zones with left-lateral strike-slip motion under the same NNE major strain. The Sue deposits and the Spitfire prospect are located on an N-S- to NE-SW-trending shear zone, while the Tri-Island showing and the Cigar Lake 


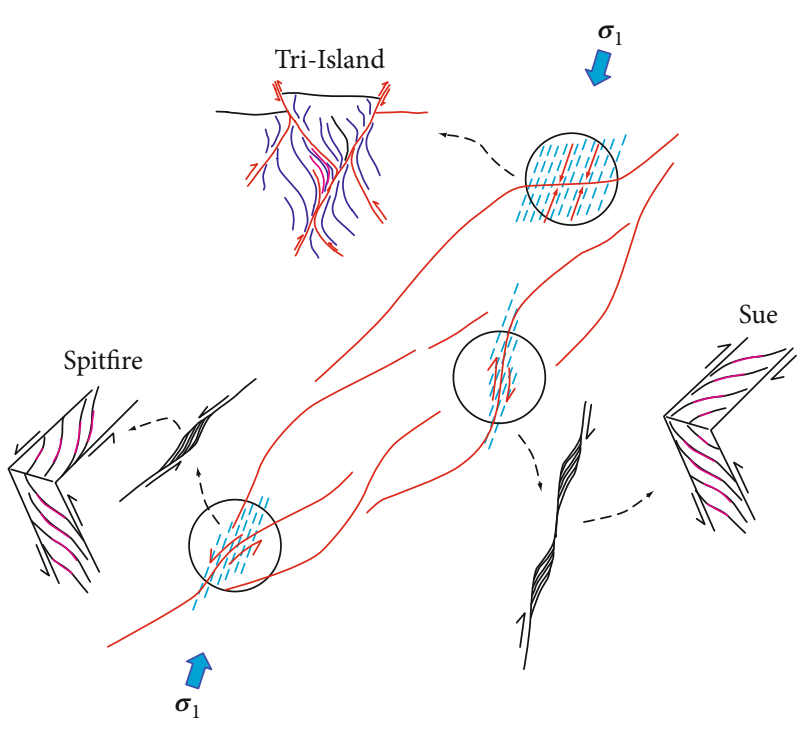

FIGURE 21: Sketch representing the reactivation of shear zones and the formation of dilational jogs and conjugated faults depending on their orientation respect to a NNE $\sigma 1$ : reverse left-lateral in Spitfire, reverse right-lateral in Sue, and conjugated in Tri-Island. Mineralization is in pink.

deposits are both located on E-W-trending structures. PostAthabasca brittle reactivation under $\mathrm{N}$ to NNE oriented $\sigma_{1}$ as deduced from this work and supported from fracture analysis in the Sue B open pit before its remediation by [49] would explain left-lateral reverse strike-slip reactivation along the preexisting NE-trending ductile shear zones, while symmetric conjugated shear zones in E-W structures would have been reactivated as conjugated faults. Two implications arise from these statements. (i) The first implication is the strong control of the inherited ductile shear patterns. NEtrending shear zones would be characterized by asymmetric shear patterns resulting from noncoaxial N-S shortening (Figure 9(b)). E-W structures were characterized, at least locally, by symmetric conjugated shear patterns as the result of N-S coaxial shortening (Figure 13(b)). Brittle reactivation under a NNE $\sigma_{1}$ would has induced (a) local dextralreverse strike-slip on shear segments oriented N-S with the opening of dilational jogs on shear bends from N-S to NE, like in the Sue area (Figure 21); (b) left-lateral reverse strike-slip on shear segments oriented NE with the opening of dilational jogs on shear bends from NE-SW- to NNEtrending, like in the Spitfire area (Figure 21); and (c) reactivation of conjugated shears along E-W structures as reverse faults like at Tri-Island (Figure 21). (ii) The second implication is that, under such a scenario, the tectonic regime into which uranium mineralization traps formed through the whole Athabasca Basin could be homogeneous and compressive. Whether the compressional phase was unique and homogeneous NNE- $\sigma_{1}$ or with various tectonic phases with variable orientation of $\sigma_{1}$ is unknown. Regardless, mineralization occurred in dilation geometrical traps that could all develop by the reactivation of shear zone bends and conjugate shear zones in a compressional regime.

\section{Conclusions}

The structural analysis performed at the Sue, Tri-Island, and Spitfire sites brings new insights about (i) the mesoscale structural controls and fracture-related traps to which basement-hosted uranium deposits are associated in the Athabasca Basin, (ii) the role the inherited ductile fabric has on the mode of brittle reactivation and the development of efficient traps for mineralization at the mesoscale, and (iii) the tectonic regime to which unconformity-related uranium deposits of the Athabasca Basin may be related.

Common mesoscale structural controls to various basement-hosted uranium deposits of the Athabasca Basin are (i) 3D dilational jog zones that form when NE-trending shear zones turn to NNE and dip lows from steeply to moderate or low (i.e., Sue deposits and Spitfire prospect) and (ii) reactivated conjugated shears along E-trending trends (i.e., Tri-Island showing).

In such, a mesoscale structural control foliation was opened forming veins parallel or oblique to foliation and local cataclasites formed. Microfracturing and corrosion/dissolution acted together as mechanisms that enhanced permeability and favoured migration of hydrothermal fluids and the formation of uranium mineralization.

The opening of dilational jog zones along NE-trending shear and the reactivation of conjugate shears along Etrending structural trends implies an N to NNE oriented compressional strain $(\sigma 1)$ during mineralization trap formation which is coherent with observed reverse left-lateral kinematic indicators. The present work and structural interpretations highlight the importance of the inherited ductile fabric as bends along NNE- to NE-trending shear zones and conjugate shear bands along E-W shear zones that were favourable for the localization of the brittle strain and the development of dilational jogs and fractures, thus enhancing fracture-related permeability, fluid flow, fault/fluid/rock interaction, and uranium mineralization in the unconformity-related uranium deposits of the Athabasca Basin.

\section{Data Availability}

Oriented data used to support the findings of this study are included in the figures within the article.

\section{Conflicts of Interest}

The authors declare that there is no conflict of interest regarding the publication of this paper.

\section{Acknowledgments}

Special thanks are due to Ryan Zerff and Odile MaufraisSmith (project geologists from Orano Canada), Scott Frostad (Vice President Exploration from Purepoint Uranium Group), and Darren Slugoski (project geologist from Purepoint Uranium Group) who facilitated access to the exploration sites and provided databases, as well as helpful information about their respective sites geology. We also thank Grant Harrison and Brandon Eccles (geophysicist/geotechnician from Orano 
Canada) for their help with the acoustic televiewer processing. We are grateful to Craig Cuts, John Robbins, and Remy Chemillac from Orano Canada, for the critical reading of the manuscript bringing on it their long experience. Thanks are due to Orano, Cameco, Denison, OURD, and Purepoint for allowing publishing these data and work. Research and publication of this article was funded by Orano and supported by the CNRS UMR 8148 GEOPS of the Universite Paris-Saclay.

\section{References}

[1] B. N. Eisenlohr, D. Groves, and G. A. Partington, "Crustalscale shear zones and their significance to Archean gold mineralization in Western Australia," Mineralium Deposita, vol. 24, pp. 1-8, 1989.

[2] F. Robert, K. H. Poulsen, K. F. Cassidy, and C. J. Hodgson, "Gold metallogeny of the Superior and Yilgarn Cratons," Economic Geology, vol. 100, pp. 1001-1033, 2005.

[3] S. Micklethwaite, H. A. Sheldon, and T. Baker, "Active fault and shear processes and their implications for mineral deposit formation and discovery," Journal of Structural Geology, vol. 32, no. 2, pp. 151-165, 2010.

[4] Y. Zhang, J. Robinson, and P. M. Schaubs, "Numerical modelling of structural controls on fluid flow and mineralization," Geoscience Frontiers, vol. 2, no. 3, pp. 449-461, 2011.

[5] C. W. Jefferson, D. J. Thomas, S. S. Gandhi et al., "Unconformity-associated uranium deposits of the Athabasca Basin, Saskatchewan and Alberta," in Mineral Deposits of Canada: A Synthesis of Major Deposit Types, W. D. Goodfellow, Ed., pp. 273-305, District Metallogeny, The Evolution Of Geological Provinces, And Exploration Methods, Geological Association of Canada, Special Publication 5, 2007.

[6] A. Anand and C. W. Jefferson, "Reactivated fault systems and their effects on outcrop patterns of thin-skinned early thrust imbrications in the Kiggavik uranium camp, Nunavut," in Geological Survey of Canada, 9 pages, Natural Resources Canada, 2017.

[7] A. Grare, A. Benedicto, O. Lacombe et al., "The contact uranium prospect, Kiggavik project, Nunavut (Canada): tectonic history, structural constraints and timing of mineralization," Ore Geology Reviews, vol. 93, pp. 141-167, 2018.

[8] A. Grare, A. Benedicto, J. Mercadier et al., "Structural controls and metallogenic model of polyphase uranium mineralization in the Kiggavik area, Nunavut, Canada," Mineralium Deposita, 2020.

[9] C. T. Harper, "The geology of the Cluff Lake uranium deposits," CIM Bulletin, vol. 71, no. 800, 1978.

[10] G. Tourigny, S. Wilson, G. Breton, and P. Portella, "Structural control and emplacement of uranium mineralization at the Sue C deposit, McClean Lake operation, northern Saskatchewan," in Summary of Investigations, vol. 2, Saskatchewan Geological Survey, Sask. Energy Mines, Misc. Rep, 2001.

[11] Z. Li, G. Chi, K. M. Bethune, D. Thomas, and G. Zaluski, "Structural controls on fluid flow during compressional reactivation of basement faults: insights from numerical modeling for the formation of unconformity-related uranium deposits in the Athabasca Basin, Canada," Economic Geology, vol. 112, no. 2, pp. 451-466, 2017.

[12] P. Martz, J. Mercadier, M. Cathelineau et al., "Formation of Urich mineralizing fluids through basinal brine migration within basement-hosted shear zones: a large-scale study of the fluid chemistry around the unconformity-related Cigar Lake U deposit (Saskatchewan, Canada)," Chemical Geology, vol. 508, pp. 116-143, 2019.

[13] J. Mercadier, A. Richard, M. C. Boiron, M. Cathelineau, and M. Cuney, "Migration of brines in the basement rocks of the Athabasca Basin through microfracture networks (P-Patch U deposit, Canada)," Lithos, vol. 115, no. 1-4, pp. 121-136, 2010.

[14] T. Cui, J. W. Yang, and I. M. Samson, “Tectonic deformation and fluid flow: implications for the formation of unconformity related uranium deposits," Economic Geology, vol. 107, no. 1, pp. 147-163, 2012.

[15] Z. Li, G. Chi, K. M. Bethune et al., "Synchronous egress and ingress fluid flow related to compressional reactivation of basement faults: the Phoenix and Gryphon uranium deposits, southeastern Athabasca Basin, Saskatchewan, Canada," Mineralium Deposita, vol. 53, no. 2, pp. 277-292, 2018.

[16] Z. Li, G. Chi, K. M. Bethune et al., "Numerical simulation of strain localization and its relationship to formation of the Sue unconformity-related uranium deposits, eastern Athabasca Basin, Canada," Ore Geology Reviews, vol. 101, pp. 1731, 2018.

[17] Y. B. Aghbelagh and J. Yang, "Effect of graphite zone in the formation of unconformity-related uranium deposits: insights from reactive mass transport modeling," Journal of Geochemical Exploration, vol. 144, pp. 12-27, 2014.

[18] D. Baudemont, J. P. Piquard, F. Ey, and J. Zimmerman, "The Sue uranium deposits, Saskatchewan, Canada," Exploration Mining Geology, vol. 2, no. 3, article 179-22, 1993.

[19] C. Sheahan, M. Fayek, D. Quirt, and C. W. Jefferson, "A combined ingress-egress model for the Kianna unconformityrelated uranium deposit, Shea Creek project, Athabasca Basin, Canada," Economic Geology, vol. 111, no. 1, pp. 225-257, 2016.

[20] S. Hillacre, K. Ansdell, B. McEwan, and M. Namara, "Structural analysis, paragenesis, and preliminary geochronology of the Arrow uranium deposit, Athabasca Basin, northern Saskatchewan, Canada: implications for controls on mineralization," in SGA Proceedings, Vol. 2, p. 743, Quebec, 2017.

[21] S. A. Bosman and P. Ramaekers, "Athabasca Group + Martin Group = Athabasca Supergroup? Athabasca Basin multiparameter drill log compilation and interpretation, with updated geological map," in Summary of Investigations 2015, Volume 2, p. 13, Saskatchewan Geological Survey, Saskatchewan Ministry of the Economy, Miscellaneous Report 20154.2, Paper A-5, 2015.

[22] C. D. Card, "Distribution and significance of crystalline rocks in the Patterson Lake uranium exploration corridor of northwest Saskatchewan," in Summary of Investigations 2017, Volume 2, p. 18, Saskatchewan Geological Survey, Saskatchewan Ministry of the Economy, Miscellaneous Report 2017-4.2, Paper A-11, 2017.

[23] P. F. Hoffman, "United plates of America, the birth of a craton-early Proterozoic assembly and growth of Laurentia," Annual Review of Earth and Planetary Sciences, vol. 16, no. 1, pp. 543-603, 1988.

[24] P. Ramaekers, C. W. Jefferson, G. M. Yeo et al., "Revised geological map and stratigraphy of the Athabasca Group, Saskatchewan and Alberta," in EXTECH IV: Geology and Uranium EXploration TECHnology of the Proterozoic Athabasca Basin, Saskatchewan and Alberta: Geological Survey of Canada, Bulletin 588, (also Geological Association of Canada, Mineral Deposits Division, Special Publication 4; Saskatchewan Geological Society, Special Publication 18), C. W. Jefferson and 
G. Delaney, Eds., pp. 155-192, Geological Survey of Canada, 2007.

[25] N. Saracoglu, R. H. Wallis, J. J. Brummer, and J. P. Golightly, "The McClean uranium deposits, northern Saskatchewan discovery," CIM Bulletin, vol. 76, no. 825, pp. 63-79, 1993.

[26] G. Chi, Z. Li, H. Chu et al., "A shallow-burial mineralization model for the unconformity-related uranium deposits in the Athabasca basin," Economic Geology, vol. 113, no. 5, pp. 1209-1217, 2018.

[27] J. F. Lewry, T. I. I. Sibbald, and C. J. Rees, "Metamorphic patterns and their relation to tectonism and plutonism in the Churchill Province of Northern Saskatchewan," Metamorphism in the Canadian Shield, Geological Survey of Canada paper, vol. 78-10, pp. 139-154, 1978.

[28] G. E. Ray, "The geology of the High Rock-Key Lake vicinity," in Saskatchewan Geological Survey, Report, vol. 197, Geological Survey of Canada, 1977.

[29] G. M. Yeo and G. Delaney, "The Wollaston supergroup, stratigraphy and metallogeny of a Paleoproterozoic Wilson cycle in the Trans-Hudson Orogen, Saskatchewan," Bull. Geol. Survey of Canada, 2007.

[30] C. D. Card, D. Pana, P. Portella, D. J. Thomas, and I. R. Annesley, "Basement rocks to the Athabasca Basin, Saskatchewan and Alberta," in EXTECH IV: Geology and Uranium EXploration TECHnology of the Proterozoic Athabasca Basin, Saskatchewan and Alberta: Geological Survey of Canada, Bulletin 588, (also Geological Association of Canada, Mineral Deposits Division, Special Publication 4; Saskatchewan Geological Society, Special Publication 18), C. W. Jefferson and G. Delaney, Eds., pp. 69-87, Geological Survey of Canada, 2007.

[31] C. D. Card, B. McEwan, and S. A. Bosman, "The Cree Lake South Project 2008: regional implications of bedrock mapping along the Virgin River transect," in Summary of Investigations 2008, Vol. 2, Saskatchewan Geological Survey, Sask, p. 23, Ministry of Energy and Resources, Misc. rep. 2008-4.2, 2008.

[32] C. D. Card, D. Pana, R. A. Stern, and N. Rayner, "New insights into the geological history of the basement rocks to the southwestern Athabasca Basin, Saskatchewan and Alberta," in EXTECH IV: Geology and Uranium Exploration Technology of the Proterozoic Athabasca Basin, Saskatchewan and Alberta, C. W. Jefferson and G. Delaney, Eds., vol. 588, pp. 119-133, Geological Survey of Canada, Bull, 2007.

[33] M. Abdelrazek, A. Benedicto, M. Fayek et al., "Permeability network, alteration and mineralization of the Spitfire basement-hosted uranium prospect, Western Athabasca, Canada," in SGA 2019 Extended Abstracts, Society for Geology Applied to Mineral Deposits, 2019.

[34] P. Alexandre, K. Kyser, D. Thomas, P. Polito, and J. Marlat, "Geochronology of unconformity-related uranium deposits in the Athabasca Basin, Saskatchewan, Canada and their integration in the evolution of the basin," Mineralium Deposita, vol. 44, no. 1, pp. 41-59, 2009.

[35] J. Cloutier, K. Kyser, G. R. Olivo, and D. Brisbin, "Geochemical, isotopic, and geochronlologic constraints on the formation of the Eagle Point basement-hosted uranium deposit, Athabasca Basin, Saskatchewan, Canada and recent remobilization of primary uraninite in secondary structures," Mineralium Deposita, vol. 46, no. 1, pp. 35-56, 2011.

[36] G. L. Cumming and D. Krstic, "The age of unconformityrelated uranium mineralization in the Athabasca Basin, northern Saskatchewan," Canadian Journal of Earth Sciences, vol. 29, no. 8, pp. 1623-1639, 1992.
[37] T. I. I. Sibbald, "Geology and genesis of the Athabasca Basin uranium deposits," in Summary of Investigations, Saskatchewan Geological Survey, Saskatchewan Energy and Mines, Miscellaneous Report 85-4, 1985.

[38] S. Ureel, M. Momayez, and Z. Oberling, "Rock core orientation for mapping discontinuities and slope stability analysis," IJRET International Journal of Research in Engineering and Technology, vol. 2, no. 7, 2013.

[39] A. Benedicto, G. Harrison, B. Eccles, and P. Ledru, "Advanced use of borehole acoustic televiewer (ATV) for structural interpretation of unconformity-related uranium deposits," Economic Geology, 2021, in press.

[40] S. Hunze and T. Wonik, "Lithological and structural characteristics of the Lake Bosumtwi impact crater, Ghana: interpretation of acoustic televiewer images," Meteoritics \& Planetary Science, vol. 42, no. 4-5, pp. 779-792, 2007.

[41] D. Moos, R. D. Jarrard, T. S. Paulsen, E. Scholz, and T. J. Wilson, "Acoustic borehole televiewer results from CRP-2/2A, Victoria Land Basin, Antarctica," Terra Antarctica, vol. 7, pp. 279-286, 2000.

[42] M. Rider, “The geological interpretation of well logs," Whittles Publishing, London, 1996.

[43] J. Zemanek, E. E. Glenn, L. Norton, and T. L. Caldwell, "Formation Evaluation by inspection with the borehole televiewer," Geophysics, vol. 35, no. 2, pp. 254-269, 1970.

[44] F. L. Paillet, W. S. Keys, and A. Hess, "Effects of lithology on televiewer-log quality and fracture interpretation," in Proceedings, 27th Annual Logging Symposium, Society of Professional Well Log Analysts, pp. 1-31, Texas, 1985.

[45] G. Lorilleux, M. Cuney, M. Jébrak, J. C. Rippert, and P. Portella, "Chemical brecciation processes in the Sue unconformity-type uranium deposits, Eastern Athabasca Basin (Canada)," Journal of Geochemical Exploration, vol. 80, no. 2-3, pp. 241-258, 2003.

[46] R. H. Wallis, N. Saracoglu, J. J. Brummer, and J. P. Golightly, "The geology of the McClean uranium deposits, northern Saskatchewan," CIM Bulletin, vol. 76, no. 825, pp. 102-131, 1993.

[47] D. H. Quirt, G. Gudmundson, C. Cutts, and C. Demange, "Sue D uranium deposit, McClean Lake property, northern mining district Saskatchewan, NTS Map Area 64L/5: 2012 mineral resource technical report (effective February 21, 2012)," AREVA Resources Canada Inc., internal report, number 12CND-99-02, 2012.

[48] G. Tourigny, D. Quirt, N. S. F. Wilson, S. Wilson, G. Breton, and P. Portella, "Geological and structural features of the Sue C uranium deposit, McClean Lake area, Saskatchewan," in EXTECH IV: Geology and Uranium Exploration TECHnology of the Proterozoic Athabasca Basin, Saskatchewan and Alberta, C. W. Jefferson and G. Delanay, Eds., vol. 588, pp. 229-247, Geological Survey of Canada, Bulletin, 2007.

[49] N. Flotté and J. L. Feybesse, "Structural geology of the Sue B deposit," AREVA internal report, N. BUM/DGS RT 08/069, 2008.

[50] P. Jeanneret, P. Goncalves, C. Durand et al., “Tectono-metamorphic evolution of the pre-Athabasca basement within the Wollaston-Mudjatik Transition Zone, Saskatchewan," Canadian Journal of Earth Sciences, vol. 53, no. 3, pp. 231-259, 2016.

[51] P. Jeanneret, P. Goncalves, C. Durand et al., "Geochronological constraints on the trans-Hudsonian tectonometamorphic evolution of the pre-Athabasca basement 
within the Wollaston-Mudjatik Transition Zone, Saskatchewan," Precambrian Research, vol. 301, pp. 152-178, 2017.

[52] D. Gapais, P. Bale, P. Choukroune, P. R. Cobbold, Y. Mahjoub, and D. Marquer, "Bulk kinematics from shear zone patterns: some field examples," Journal of Structural Geology, vol. 9, no. 5-6, pp. 635-646, 1987.

[53] P. Martz, M. Cathelineau, J. Mercadier et al., "C-O-H-N fluids circulations and graphite precipitation in reactivated Hudsonian shear zones during basement uplift of the WollastonMudjatik Transition Zone: example of the Cigar Lake U deposit," Lithos, vol. 294-295, pp. 222-245, 2017.

[54] A. Benedicto, C. MacKay, S. Frostad, D. Slugoski, and P. Ledru, Uranium Mineralization and Structural Controls in the Spitfire Prospect, Hook Lake Project, Patterson Lake Trend, Canada, Orano, Quebec City, 2017.

[55] C. D. Card and J. Noll, "Host-rock protoliths, pre-ore metasomatic mineral assemblages and textures, and exotic rocks in the Western Athabasca Basin: ore-system controls and implications for the unconformity-related uranium model," in Summary of Investigations 2016, Volume 2, Saskatchewan Geological Survey, p. 19, Saskatchewan Ministry of the Economy, Miscellaneous Report 2016-4.2, Paper A-8, 2016.

[56] G. Lorilleux, M. Jébrak, M. Cuney, and D. Baudemont, "Polyphase hydrothermal breccias associated with unconformityrelated uranium mineralization (Canada): from fractal analysis to structural significance," Journal of Structural Geology, vol. 24, no. 2, pp. 323-338, 2002.

[57] G. Breton, R. Campbell, P. Portella, and D. Bingham, "McClean Lake project, 2003 activities and results," vol I to IV. Cogema (actually Orano) internal report, 2003. 